\title{
Analysing smallholders' behaviour on Sumatra: An ex ante policy analysis and investigation of experiments' external validity under consideration of risk
}

\author{
Dissertation \\ to obtain the Ph.D. degree \\ at the Faculty of Agricultural Sciences, \\ Georg-August-University Göttingen, Germany \\ presented by \\ Stefan Moser \\ born in Melk, Austria
}


1. Name of supervisor: Prof. Dr. Oliver Mußhoff

2. Name of first co-supervisor: Prof. Dr. Bernhard Brümmer

3. Name of second co-supervisor: Jun.-Prof. Dr. Meike Wollni

Date of dissertation: July $13^{\text {th }}, 2015$ 


\section{Acknowledgements}

The submission of my dissertation is a good occasion to look back and be thankful for many things that happened to me.

First of all, I thank my supervisor Prof. Oliver Mußhoff for the academic support. He provided an excellent working environment that enhanced high-quality research. His availability for fruitful discussions and his valuable advice are outstanding and I never took that for granted. With his demanding working attitude, he stimulated my progress resulting in an effective working time and a steep learning curve.

Moreover, there are numerous people who supported me with their knowledge and experience. It would be beyond the scope of this acknowledgment to name all of them, thus I name Jun.-Prof. Meike Wollni and Prof. Bernhard Brümmer as the who gave valuable advice and comments for my papers and who also serve as co-supervisors for this dissertation. Additionally, I thank Prof. Christoph Weiss for my year as research assistant at the Vienna University of Economic and Business, where I made useful experiences which prepared me for writing this dissertation.

I am also very grateful for the colleagues who accompanied me during the last years. I very much enjoyed the cooperative, supportive and friendly working atmosphere that I experienced within the CRC 990 as well as of the chair. We had a good time together and there have been many wonderful moments I will never forget. Thank you guys!

A special thanks also goes to my Indonesian assistants Fauzan and Zulfi. Without their patience for my slow understanding of cultural differences, it would not have been possible to conduct the field work in a reasonable way.

Another thanks goes to Prof. em. Dr. Wilhelm Brandes, who shared his office with me during the last years. Despite the age difference of almost 50 years, we always found important things about politics, economics and more to discuss, which I always enjoyed.

This dissertation was written within the research project CRC 990 titled "Ecological and Socio-Economic functions of tropical lowland rainforest transformation systems" and funded by the German Research Foundation (DFG). I therefore thank the DFG for the funding of my work for this project; without their financial support, it would not have been possible for me to finalise my $\mathrm{PhD}$.

I finally thank many persons I met aside the academic world. I arrived in Göttingen as a stranger (from abroad $^{\wedge \wedge}$ ); however, the friendlyness and openness of the people here allowed me to feel at home soon. I am grateful for meeting all of you and for the wonderful 
time I was allowed to have here in Göttingen. Thus, not only my professional skills developed, but also my personality, which in my opinion is the more important thing. Last but certainly not least, I want to thank my family, and here especially my mom, for the livelong support I received. Danke Mama! 


\section{Table of Contents}

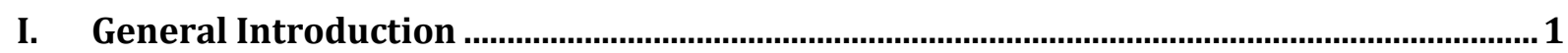

1. Ex ante evaluation of policy measures …….............................................................................

2. Comparing the use of risk-influencing production inputs and experimentally measured

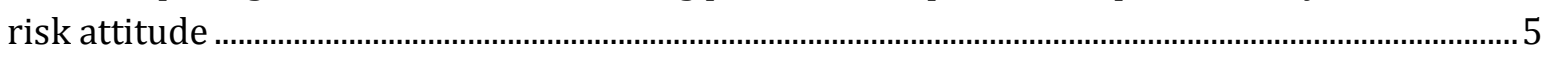

3. Research relevance and outline of the dissertation ................................................................

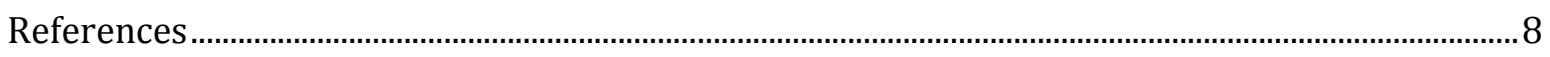

II. Ex ante evaluation of policy measures: Effects of reward and punishment for fertiliser

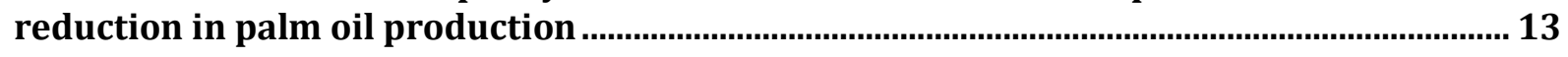

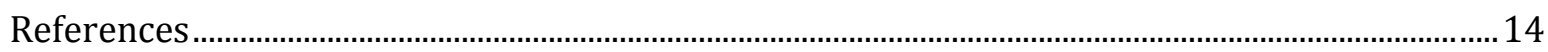

III. Comparing the use of risk-influencing production inputs and experimentally measured risk attitude: Do decisions of Indonesian small-scale rubber farmers match?. 18

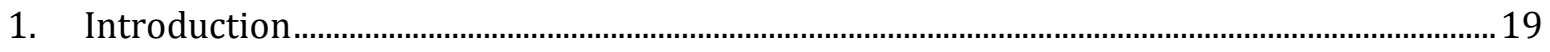

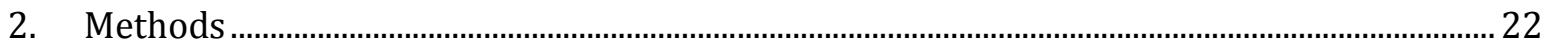

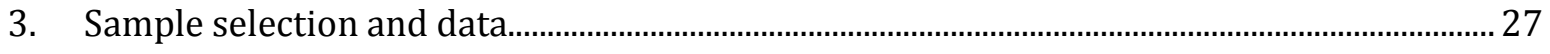

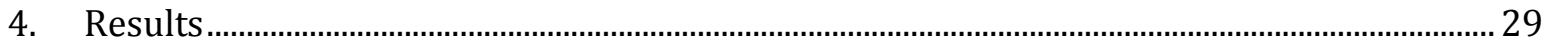

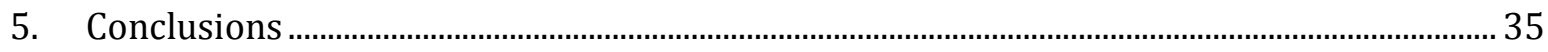

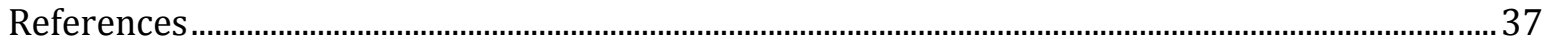

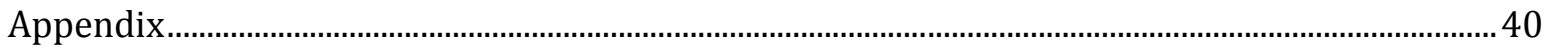

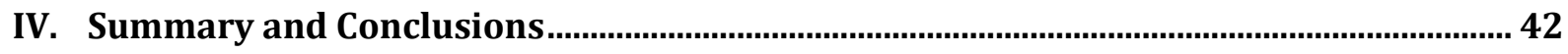

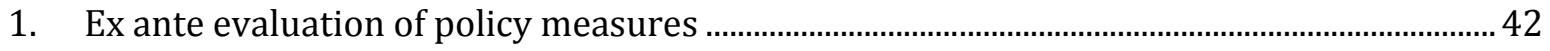

2. Comparing the use of risk-influencing production inputs and experimentally measured

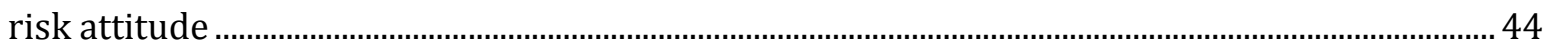

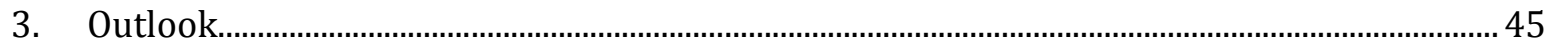

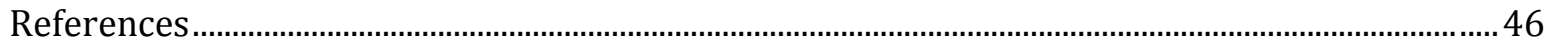




\section{General Introduction}

Agricultural production creates negative externalities on a global scale, e.g., deforestation, loss in biodiversity, loss of cropland or carbon induced climate change (Tilman et al., 2001; Kitzes et al., 2008; Kastner et al., 2012; Garnett et al., 2013). From 1980 to 2000, over 80\% of newly established agricultural land was developed on former tropical rainforest ground. However, since the world population is expected to grow from approximately 7.2 billion in 2014 to more than 9.5 billion people by 2050 (FAOSTAT, 2015), a highly dynamic development in agricultural production is demanded. This development might further increase negative externalities and environmental problems (Garnett et al., 2013).

Palm oil is an example of an especially dynamic development in agricultural production. This oil is widely-used around the world and can be found in a variety of products such as food, cosmetics or as biofuel. However, it is most commonly used globally as vegetable oil, with 50 million tons being produced in 2012 (FAOSTAT, 2013). Currently, Indonesia is the largest palm oil producer in the world. Starting in the 1960s at a relative moderate level, palm oil production in Indonesia has developed remarkably, with a goal of further increasing its production from 23.6 million tons in 2012 to 40 million tons by 2020 (UNCTAD, 2013). Within Indonesia, the Jambi province, on the island of Sumatra, has experienced especially dynamic development in palm oil production (Laumonier et al., 2010; Wilcove and Koh, 2010), which was primarily driven by private sector companies and small scale farmers (Zen et al., 2006).

The tremendous development in oil palm cultivation carries drastic consequences for the environment. Thus, the industry's expansion leads to high rates of deforestation, habitat fragmentation and losses in biodiversity (Koh and Wilcove, 2008, Margono et al., 2014). Moreover, due to the emission of greenhouse gases, such as $\mathrm{CO}_{2}$, there are negative consequences for the atmosphere (Reijnders and Huijbregts, 2008). The exaggerate use of fertiliser in palm oil cultivation causes negative externalities. In this context, Sekhon (1995) shows that an exaggerated use of $\mathrm{N}$-fertiliser leads to more polluted ground water in developing countries, specifically those located in the humid tropics. Moreover, fertiliser use in humid tropical climates can cause NOx and other greenhouse gas emissions (Keller and Matson, 1994; Veldkamp and Keller, 1997; Palm et al., 2002; Veldkamp et al., 2008). Additionally, fertiliser can cause ground-level ozone in oil palm plantations at concentrations which are detrimental to human health (Hewitt et al., 2009). These 
environmental problems, especially with regard to the overuse of fertiliser, demand effective, sustainable and efficient policy measures.

In Jambi province, rubber is the a major crop trees and together with oil palm it generate the majority of farmers' income. About the half of the cultivated land is used for rubber production, which usually is managed by small-scale farmers (Statistical Year Book of Estate Crops, 2012). Therefore, it is the logical alternative to the problematic oil palm cultivation and demands for investigations. Based on the economic relevance of rubber, income risk caused through output risk in rubber production is a crucial concern in this region. However, it is long proven that production inputs have an influence on output risk (Just and Pope, 1978, 1979). Nevertheless, for rubber production there is little knowledge about how production inputs influence output risk.

This dissertation consists of two papers: The first paper is focused on an ex ante evaluation of policy measures for fertiliser reduction for small scale oil palm farmers in Indonesia. The second paper evaluates inputs' influence on output risk for rubber cultivation and the external validity of experimentally measured risk attitudes for rubber farmers. Both articles are conducted almost with the same farmers. In the following sections, the problem statement and the objectives of these two papers are briefly discussed.

\section{Ex ante evaluation of policy measures}

The overuse of fertiliser, especially in oil palm cultivation, demands for an appropriate policy measure. It is advisable to test policy measures before they are introduced; a low cost opportunity for doing is through ex ante tests. For such tests, the often used rational choice approach has recently been challenged through new economic insight; thus, an alternative approach is demanded (Veetil, 2011). A promising alternative for evaluating policy measures, especially in developing countries, is by conducting economic experiments (Viceisza, 2012). Therefore, we apply a business simulation game, embedded in a framed field experiment (Harrison and List, 2004). For such experiments however, it is essential that the external validity, i.e., results from the laboratory, can be extrapolated to the world beyond. The discussion surrounding external validity varies widely in the literature (Levitt and, List 2007; Camerer, 2011). In any case, further examples which contribute to this discussion about the external validity of experimentally gained results are desired.

An incentive designs for policy measures can differ in several ways. Balliet et al. (2011) discuss a number of possible differences, primarily whether a reward for desired or a 
punishment for undesired behaviour is more successful. Other differentiations include the probability of occurrence for a reward or a punishment when a specific behaviour is desired or undesired, respectively, or the reaction towards different magnitudes of an incentive. By combining an incentives' probability with its' magnitude, the effect on the expected income of such an incentive can be determined (Becker, 1974). Balliet et al. (2011) lists further possibilities to differentiate incentive designs, e.g., the costs for giving an incentive, centralised vs. decentralised source of incentive, the number of iterations, the type of dilemma or the cost-to-fine ratio. Additionally, Sutter et al. (2010) distinguish whether incentives are chosen by participants compared to externally determined incentive mechanisms. In our article, however, we investigate in analysing reward and punishment with different probabilities.

In theory, a perfectly rational, profit maximising agent will act independently of differences in incentive design as long as the effect on expected income is constant (Becker, 1974). However, the assumption of a perfectly rational, profit maximising agent has been challenged in recent years (Veetil, 2011). For comparing reward and punishment incentives, which is comparable to receiving gains and losses, there is extensive literature which discusses the differences in participants' reactions. Kahneman (2011) provides several examples from various contexts which show that people are generally more motivated to avoid losses than to gain profits, e.g., for cab drivers in New York (Camerer et al., 1997), for messenger services in Switzerland (Fehr and Goette, 2007) or for international professional golf players (Pope and Schweitzer, 2011). Moreover, Heath et al. (1999) found that, with the condition that there is a reference point, people are more motivated to avoid losses than to gain profits. According to these articles, punishment is expected to create stronger reactions than reward. In contrast, a meta-analysis including 187 effect sizes from Balliet et al. (2011) indicates that reward and punishment have similar positive effects on cooperation. Therefore, despite strong evidence for loss aversion, it remains unclear if there is also a stronger reactions, i.e., a higher effectiveness, towards punishment compared to reward.

The literature also discusses the effects of gains and losses occurring with different probabilities. With respect to losses, Kahneman (2011) states that a low probability of occurrence leads to risk-avoiding behaviour. Therefore, this would imply that participants react more strongly towards uncertain punishment compared to a certain punishment, holding constant the effects on expected income. Additional research by Block and Vernon (1995) and Anderson and Stafford (2003) strengthen this expectation. The literature comparing certain and uncertain gains is limited. However, Kahneman (2011) claims risk- 
seeking behaviour for gains with a low probability. This allows us to anticipate that participants react more strongly towards an uncertain than towards a certain reward, assuming constant effects on expected income. Volpp et al. (2008) present a study which compares certain and uncertain reward, but were unable to find a significant difference between the two.

The effects of differently designed incentives on sustainability and efficiency are also discussed in the literature. With regard to sustainability, Anderson and Stafford (2003) found a negative effect through punishment in a repeated public good game. Balliet et al. (2011) found that incentives increase cooperative behaviour in iterated experiments, but it cannot be determined whether this effect is stronger for reward or for punishment. For efficiency, a positive effect through punishment is found in several studies (Fehr and Gächter, 2000; Gächter et al., 2008; Balliet et al., 2011). Moreover, it is shown that reward is more efficient than punishment (Sefton et al., 2007; Rand et al., 2009). However, little is known in regards to how sustainability and efficiency are influenced by the incentives' probabilities of occurrence.

Ex ante tests are a good opportunity for testing policy measures in advance at low costs. Thus far, most ex ante policy evaluations are based on the rational choice approach, which has recently been challenged in the field of behavioural economics. Thus, alternative approaches are necessary (Veetil, 2011). A promising alternative for evaluating policy recommendations, especially in developing countries, is by conducting economic experiments (Viceisza, 2012).

The first article of this dissertation is titled "Ex ante evaluation of policy measures: Effects of reward and punishment for fertiliser reduction in palm oil production". In this article, differently designed policy measures intended to reduce the use of fertiliser are tested ex ante with small scale oil palm farmers in Indonesia. To be more precise, we test if incentives with constant effects on expected income, but designed as being obtained through either reward or punishment with different probabilities to occur, cause different reactions from the participating farmers. The hypotheses of the aforementioned article are "For the same effect on expected income, the H1: effectiveness, H2: sustainability, H3: efficiency of an incentive is independent of its design, i.e., reward or punishment, with different magnitudes and probabilities of occurrence". 


\section{Comparing the use of risk-influencing production inputs and experimentally measured risk attitude}

Output risk and risk attitude are among the major drivers for production decisions in agriculture. Thus, it is not surprising that analysing risk and risk attitude is a primary focus in the research pertaining to agriculture (Chavas et al., 2010). In this context, Hellerstein et al. (2013) discuss the importance of understanding the risk attitude/production decision relationship since it helps policy makers, as well as farmers to accommodate to changing economic and environmental circumstances.

It is not easy to determine how risk and risk attitude affects farmers' production decisions. (Just, 2001; Just and Pope, 2003). However, risk attitude has been experimentally measured long since (Binswanger, 1980). Moreover, Holt and Laury (2002) also described a wellaccepted method to experimentally measure the risk attitude (Anderson and Mellor, 2008). Ihli and Musshoff (2013) further adapted the Holt-Laury (HL) method to measure the risk attitude so that it can be applied to people with limited formal education. By accounting for this adaptation, the HL method can be applied for measuring the risk attitude in rural areas of developing countries.

For this research, we focus on output risk, i.e., output variance, to evaluate farmers' behaviour towards risk. Farmers' production decisions, e.g., through input use, have a crucial influence on output risk, and thus, also on farmers' income risk. Since income risks represent a major concern in farmers' lives, decisions related to the use of risk-influencing inputs are a good option for measuring farmers' behaviour towards risk in the field. Just and Pope $(1978 ; 1979)$ describe a method to simultaneously estimate production inputs' influence on output level, as well as output risk in agricultural production. Several studies have applied and further extended this approach to fit various contexts, thus proving its relevance (Chavas and Holt, 1996; Bar-Shira et al., 1997; Kumbhakar, 2001; 2002a; 2002b; Abdulkadri, 2003; Isik and Khanna, 2003; Kumbhakar and Tveterås, 2003; Barrett et al., 2004; Di Falco and Chavas, 2009; Gardebroek et al., 2010; Tiedemann and Latacz-Lohmann, 2013).

The external validity of experimentally gathered results, what is denoted as "insights gained in the lab can be extrapolated to the world beyond" (Levitt and List, 2007: 153), is controversially discussed. On the one hand, some economists argue against the external validity of experiments; in this context, Levitt and List (2007) state that the systematic difference from the lab to most naturally occurring environments is hindering external 
validity of the results. On the other hand, Camerer (2011) states that all empirical studies help to understand the general way in which individual characteristics, incentives, rules and endowments influence economic behaviour. Camerer argues in favour of the external validity of results from lab experiments and states that, with sufficient information, one could account for the differences between the lab and the field. In other words, this means that a Lab dummy variable would not be significant in a regression with a sufficient data set including lab and non-lab information. Furthermore, Roe and Just (2009) argue that there is a trade-off between internal validity, i.e., that observed correlations are causal, and the external validity of experiments.

Many investigations comparing field decisions towards risk and experimentally measured risk attitude have already been concluded. Engle-Warnick et al. (2007) obtained experimental results that have helped to predict crop diversification for farmers in Peru. Moreover, Hill (2009) explain the production behaviour with the stated risk attitude for coffee producers in Uganda, whereas Barham et al. (2014) found only a small effect from risk aversion on the adoption of genetically modified plants. With respect to nonagricultural decisions, Anderson and Mellor (2009) also found an expected relationship between experimentally measured risk attitude and decisions towards health and safety. Contrarily, Hellerstein et al. (2013) found unexpected results between field and experimental decisions. In their example, farmers with a higher risk aversion in the experiment have less diversified operation and less crop insurances. More examples which compare the internal and external validity of experimentally obtained results are certainly desirable. However, experimentally obtained results pertaining to risk attitude and production decisions towards risk, as evaluated with a Just-Pope (JP) production function, have not been previously compared. Influencing output risk with production inputs is a tool which practically every farmer can utilize. Thus, it is especially relevant because it enables farmers to manage their risk independently of their availability to hold insurance, have production diversification, obtain non-farm labour or utilize other tools.

The second article of this dissertation is "Comparing the use of risk-influencing production inputs and experimentally measured risk attitude: Do decisions of Indonesian small-scale rubber farmers match?". In this article, the use of risk-influencing production inputs and the experimentally measured risk attitude are compared in the case of small-scale rubber farmers in Indonesia. The hypotheses which are tested in the aforementioned article are "H1: The amount of used production inputs has an influence on output risk" and "H2: More risk-averse farmers use more risk-reducing and less risk-increasing inputs". 


\section{Research relevance and outline of the dissertation}

The studies presented in this dissertation are embedded in the Collaborative Research Centre 990 (CRC 990) under the title "Ecological and Socioeconomic Functions of Tropical Lowland Rainforest Transformation Systems". The present research project is funded by the German Research Foundation (DFG) and is conducted in the Jambi province on the Indonesian Island of Sumatra. The project is an interdisciplinary and international research cooperation where social and natural scientists from German and Indonesian universities work together. The general objective of this project is to provide knowledge-based guidelines to protect ecological functions of tropical forests and their transformation systems, while human welfare is improved. Several phases are planned for the CRC 990, and since we are part of the first phase, our results and conclusions can also be seen as a basis for continuing with this research.

The dissertation is structured as follows: In Chapter II, the article titled "Ex ante evaluation of policy measures: Effects of reward and punishment for fertiliser reduction in palm oil production" is presented. This article has been accepted by the "Journal of Agricultural Economics". The focus of this article is ex ante testing experiment for policy measures aimed at reducing the use of fertiliser in palm oil production. Chapter III presents the article "Comparing the use of risk-influencing production inputs and experimentally measured risk attitude: Do decisions of Indonesian small-scale rubber farmers match?". A previous version of this article has been published in the "EFForTS Discussion Paper Series No. 14". This article compares decisions towards risk in rubber production with experimentally measured risk attitude. Finally, Chapter IV includes a summary of the research, as well as a conclusion for the presented articles. 


\section{References}

Abdulkadri, A.O. (2003). 'Estimating risk aversion coefficients for dry land wheat, irrigated corn and dairy producers in Kansas', Applied Economics, Vol. 35: 825-834.

Anderson, L.R. and Mellor, J.M. (2008). 'Predicting health behaviors with an experimental measure of risk preference', Journal of health economics, Vol. 27: 1260-1274.

Anderson, L.R. and Mellor, J.M. (2009). 'Are risk preferences stable? Comparing an experimental measure with a validated survey-based measure', Journal of Risk and Uncertainty, Vol. 39: 137-160.

Anderson, L.R. and Stafford, S.L. (2003). 'Punishment in a regulatory setting: experimental evidence from the VCM', Journal of Regulatory Economics, Vol. 24: 91-110.

Balliet, D., Mulder, L.B. and Van Lange, P.A.M. (2011). 'Reward, punishment, and cooperation: A meta-analysis', Psychological Bulletin, Vol. 137: 594-615.

Barham, B., Chavas, J.P., Fitz, D., Rios Salas, V. and Schechter, L. (2014). 'The roles of risk and ambiguity in technology adoption', Journal of Economic Behavior and Organization, Vol. 97: 204-218.

Bar-Shira, Z., Just, R.E. and Zilberman, D. (1997). 'Estimation of farmers' risk attitude: an econometric approach', Agricultural Economics, Vol. 17: 211-222.

Barrett, C.B., Moser, C.M., McHugh, O.V. and Barison, J. (2004). 'Better technology, better plots, or better farmers? Identifying changes in productivity and risk among Malagasy rice farmers', American Journal of Agricultural Economics, Vol. 86: 869-888.

Becker, G.S. (1974). 'Crime and punishment: An economic aproach', in G.S. Becker and W.M. Landes (eds.), Essays in the Economics of Crime and Punishment (New York: National Bureau of Economic Research, 1974, 1-54).

Binswanger, H.P. (1980). 'Attitudes toward risk: Experimental measurement in rural India', American Journal of Agricultural Economics, Vol. 62: 395-407.

Block, M.K. and Vernon, G.E. (1995). 'Some Experimental Evidence on Differences between Student and Prisoner Reactions to Monetary Penalties and Risk', The Journal of Legal Studies, Vol. 24: 123-138.

Camerer, C. (2011). 'The promise and success of lab-field generalizability in experimental economics: A critical reply to Levitt and List', Working Paper 1977749, (Los Angeles: Social Science Research Network).

Camerer, C., Babcock, L., Loewenstein, G. and Thaler, R. (1997). 'Labor Supply of New York City Cabdrivers: One Day at a Time', The Quarterly Journal of Economics, Vol. 112: 407441.

Chavas, J.P., Chambers, R.G. and Pope, R.D. (2010). 'Production economics and farm management: a century of contributions', American Journal of Agricultural Economics, Vol. 92: 356-375. 
Chavas, J.P. and Holt, M.T. (1996). 'Economic behavior under uncertainty: A joint analysis of risk preferences and technology', The Review of Economics and Statistics, Vol. 78: 329335.

Di Falco, S. and Chavas, J.P. (2009). 'On crop biodiversity, risk exposure, and food security in the highlands of Ethiopia', American Journal of Agricultural Economics, Vol. 91: 599611.

Engle-Warnick, J., Escobal, J. and Laszlo, S. (2007). 'Ambiguity aversion as a predictor of technology choice: experimental evidence from Peru', Working Paper 2007s-01, (Montreal: Social Science Research Network).

FAOSTAT. (2013). Data About Crop Production. Available at: http://faostat3.fao.org/faostatgateway/go/to/download/Q/*/E, (Rome: Food and Agricultural Organization of the United Nations. Statistics Division (FAOSTAT), last accessed 18 October 2013).

FAOSTAT. (2015). Data About Crop Production. Available at: http://faostat3.fao.org/download/O/OA/E, (Rome: Food and Agricultural Organization of the United Nations. Statistics Division (FAOSTAT), last accessed 28 April 2015).

Fehr, E. and Gächter, S. (2000). 'Cooperation and punishment in public goods experiments', American Economic Review, Vol. 90: 980-994.

Fehr, E. and Goette, L. (2007). 'Do Workers Work More if Wages Are High? Evidence from a Randomized Field Experiment', The American Economic Review, Vol. 97: 298-317.

Gächter, S., Renner, E. and Sefton, M. (2008). 'The long-run benefits of punishment', Science, Vol. 322: 1510.

Gardebroek, C., Chavez, M.D. and Lansink, A.O. (2010). 'Analysing production technology and risk in organic and conventional Dutch arable farming using panel data', Journal of Agricultural Economics, Vol. 61: 60-75.

Garnett, T., Appleby, M.C., Balmford, A., Bateman, I.J., Benton, T.G., Bloomer, P., Burlingame, B., Dawkins, M., Dolan, L., Fraser, D., Herrero, M., Hoffmann, I., Smith, P., Thornton, P.K., Toulmin, C., Vermeulen, S.J., Godfray, H.C.J. (2013). 'Sustainable intensification in agriculture: premises and policies', Science, Vol. 341: 33-34.

Harrison, G.W. and List, J.A. (2004). 'Field experiments', Journal of Economic Literature, Vol. 42: 1009-1055.

Heath, C., Larrick, R.P. and Wu, G. (1999). 'Goals as Reference Points', Cognitive Psychology, Vol. 38: 79-109.

Hellerstein, D., Higgins, N. and Horowitz, J. (2013). 'The predictive power of risk preference measures for farming decisions', European Review of Agricultural Economics, Vol. 40: 807-833.

Hewitt, C.N., MacKenzie, A.R., Di Carlo, P., Di Marco, C.F., Dorsey, J.R., Evans, M., Fowler, D., Gallagher, M.W., Hopkins, J.R., Jones, C.E., Langford, B., Lee, J.D., Lewis, A.C., Lim, S.F., McQuaid, J., Misztal, P., Moller, S.J., Monks, P.S., Nemitz, E., Oram, D.E., Owen, S.M., Phillips, G.J., Pugh, T.A.M., Pyle, J.A., Reeves, C.E., Ryder, J., Siong, J., Skiba, U. and 
Stewart, D.J. (2009). 'Nitrogen management is essential to prevent tropical oil palm plantations from causing ground-level ozone pollution', Proceedings of the National Academy of Sciences, Vol. 106: 18447-18451.

Hill, V.R. (2009). 'Using stated preferences and beliefs to identify the impact of risk on poor households', The Journal of Development Studies, Vol. 45: 151-171.

Holt, C.A. and Laury, S.K. (2002). 'Risk aversion and incentive effects', American economic review, Vol. 92: 1644-1655.

Ihli, H.J. and Musshoff, O. (2013) 'Investment Behavior of Ugandan Smallholder Farmers: An Experimental Analysis', GlobalFood Discussion Papers 21, (Göttingen: University Göttingen).

Isik, M. and Khanna, M. (2003). 'Stochastic technology, risk preferences, and adoption of site-specific technologies', American Journal of Agricultural Economics, Vol. 85: 305317.

Just, R.E. (2001). 'Addressing the changing nature of uncertainty in agriculture', American Journal of Agricultural Economics, Vol. 83: 1131-1153.

Just, R.E. and Pope, R.D. (1978). 'Stochastic specification of production functions and economic implications', Journal of Econometrics, Vol. 7: 67-86.

Just, R.E. and Pope, R.D. (1979). 'Production function estimation and related risk considerations', American Journal of Agricultural Economics, Vol. 61: 276-284.

Just, R.E. and Pope, R.D. (2003). 'Agricultural risk analysis: adequacy of models, data, and issues', American Journal of Agricultural Economics, Vol. 85: 1249-1256.

Kahneman, D. (2011). Thinking, Fast and Slow (New York: Farrar, Straus and Giroux).

Kastner, T., Rivas, M.J.I., Koch, W. and Nonhebel, S. (2012). 'Global changes in diets and the consequences for land requirements for food', Proceedings of the National Academy of Sciences, Vol. 109: 6868-6872.

Keller, M. and Matson, P.A. (1994). 'Biosphere-Atmosphere Exchange of Trace Gases in the Tropics: Evaluating the Effects of Land Use Changes', Global Atmospheric-Biospheric Chemistry, Vol. 48: 103-117.

Kitzes, J., Wackernagel, M., Loh, J., Peller, A., Goldfinger, S., Cheng, D. and Tea, K. (2008): 'Shrink and share: humanity's present and future Ecological Footprint', Philosophical Transactions of the Royal Society B: Biological Sciences, Vol. 363: 467-475.

Koh, L.P. and Wilcove, D.S. (2008). 'Is oil palm agriculture really destroying tropical biodiversity?', Conservation Letters, Vol. 1: 60-64.

Kumbhakar, S.C. (2001). 'Risk preferences under price uncertainties and production risk', Communications in Statistics-Theory and Methods, Vol. 30: 1715-1735.

Kumbhakar, S.C. (2002a). 'Risk preference and productivity measurement under output price uncertainty', Empirical Economics, Vol. 27: 461-472.

Kumbhakar, S.C. (2002b). 'Specification and estimation of production risk, risk preferences and technical efficiency', American Journal of Agricultural Economics, Vol. 84: 8-22. 
Kumbhakar, S.C. and Tveterås, R. (2003). 'Risk preferences, production risk and firm heterogeneity', The Scandinavian Journal of Economics, Vol. 105: 275-293.

Laumonier, Y., Uryu, Y., Stüwe, M., Budiman, A., Setiabudi, B. and Hadian, O. (2010). 'Ecofloristic sectors and deforestation threats in Sumatra: identifying new conservation area network priorities for ecosystem-based land use planning', Biodiversity and conservation, Vol. 19: 1153-1174.

Levitt, S. and List, J. (2007). 'What Do Laboratory Experiments Measuring Social Preferences Reveal about the Real World?', The Journal of Economic Perspectives, Vol. 21: 153-174.

Margono, B.A., Potapov, P.V., Turubanova, S., Stolle, F. and Hansen, M.C. (2014). 'Primary forest cover loss in Indonesia over 2000-2012', Nature Climate Change, Vol. 4: 730735.

Palm, C.A., Alegre, J.C., Arevalo, L., Mutuo, P.K., Mosier, A.R. and Coe, R. (2002). 'Nitrous oxide and methane fluxes in six different land use systems in the Peruvian Amazon', Global Biogeochemical Cycles, Vol. 16: 1-21.

Pope, D.G. and Schweitzer, M. (2011). 'Is Tiger Woods loss averse? Persistent bias in the face of experience, competition, and high stakes', The American Economic Review, Vol. 101: 129-157.

Rand, D.G., Dreber, A., Ellingsen, T., Fudenberg, D. and Nowak, M.A. (2009). 'Positive interactions promote public cooperation', Science, Vol. 325: 1272-1275.

Reijnders, L. and Huijbregts, M.A.J. (2008). 'Palm oil and the emission of carbon-based greenhouse gases', Journal of Cleaner Production, Vol. 16: 477-482.

Roe, B.E. and Just, D.R. (2009). 'Internal and external validity in economics research: Tradeoffs between experiments, field experiments, natural experiments, and field data', American Journal of Agricultural Economics, Vol. 91: 1266-1271.

Sefton, M., Shupp, R. and Walker, J.M. (2007). 'The effect of rewards and sanctions in provision of public goods', Economic Inquiry, Vol. 45: 671-690.

Sekhon, G.S. (1995). 'Fertilizer-N use efficiency and nitrate pollution of groundwater in developing countries', Journal of Contaminant Hydrology, Vol. 20: 167-184.

Statistical Year Book of Estate Crops. (2012). (Jambi Province: Estate Cop Services of Jambi Province).

Sutter, M., Haigner, S. and Kocher, M.G. (2010). 'Choosing the Carrot or the Stick? Endogenous Institutional Choice in Social Dilemma Situations', Review of Economic Studies, Vol. 77: 1540-1566.

Tiedemann, T. and Latacz-Lohmann, U. (2013). 'Production Risk and Technical Efficiency in Organic and Conventional Agriculture - The Case of Arable Farms in Germany', Journal of Agricultural Economics, Vol. 64: 73-96.

Tilman, D., Fargione, J., Wolff, B., D'Antonio, C., Dobson, A., Howarth, R., Schindler, D., Schlesinger, W.H., Simberloff, D. and Swackhamer, D. (2001). 'Forecasting agriculturally driven global environmental change', Science, Vol. 292: 281-284. 
UNCTAD. (2013). Infocomm-AAACP Products-Palm Oil. Available at: http://www.unctad.info/en/Infocomm/AACP-Products/Palm-oil (Geneva: UNCTAD, last accessed 21 October 2013).

Veetil, V. (2011). 'Conceptions of rationality in law and economics', European Journal of Law and Economics, Vol. 31: 199-228.

Veldkamp, E. and Keller, M. (1997). 'Nitrogen oxide emissions from a banana plantation in the humid tropics', Journal of Geophysical Research: Atmospheres, Vol. 102: 1588915898.

Veldkamp, E., Purbopuspito, J., Corre, M.D., Brumme, R. and Murdiyarso, D. (2008). 'Land use change effects on trace gas fluxes in the forest margins of Central Sulawesi, Indonesia', Journal of Geophysical Research: Biogeosciences,: Vol. 113: 1-11.

Viceisza, A. (2012). Treating the field as a lab: A basic guide to conducting economics (Washington, DC: International Food Policy Research Institute (IFPRI)).

Volpp, K.G., John, L.K., Troxel, A.B., Norton, L., Fassbender, J. and Loewenstein, G. (2008). 'Financial incentive-based approaches for weight loss', JAMA, Vol. 300: 2631-2637.

Wilcove, D.S. and Koh, L.P. (2010). 'Addressing the threats to biodiversity from oil-palm agriculture', Biodiversity and conservation, Vol. 19: 999-1007.

Zen, Z., Barlow, C. and Gondowarsito, R. (2006). 'Oil palm in Indonesian socio-economic improvement: a review of options', Oil Palm Industry Economic Journal, Vol. 6: 18-29. 


\title{
II. Ex ante evaluation of policy measures: Effects of reward and punishment for fertiliser reduction in palm oil production
}

\section{Authors: Stefan Moser and Oliver Mußhoff}

Published in: Journal of Agricultural Economics (2015), doi: 10.1111/1477-9552.12114

\begin{abstract}
Palm oil production creates negative externalities, e.g., through intensive fertiliser application. Policies to limit externalities need an effective, sustainable and efficient measure We use a business simulation game in a framed field experiment in Indonesia to test ex ante different incentives for reducing such negative externalities. This setting allows inclusion of adequate contextual features, required for reasonable ex ante evaluation of policy measures. The different designs of the test incentives (either a reward or punishment) varied in their magnitude and probability of occurrence but with constant effects on expected income. Results show that participants react differently to these incentives, indicating that the design can contribute significantly to effectiveness, sustainability or efficiency. A high reward with a low probability was found to be the most effective and sustainable incentive. Moreover, for the most efficient design, a low and certain reward is indicated.
\end{abstract}

\section{Keywords}

Ex ante policy impact analysis, reward, punishment, framed field experiment, business simulation game, palm oil production, Indonesia, fertiliser use

\section{JEL classifications}

C91, Q18, Q52 


\section{References}

Anderson, L.R. and Stafford, S.L. (2003). 'Punishment in a regulatory setting: experimental evidence from the VCM', Journal of Regulatory Economics, Vol. 24: 91-110.

Balliet, D., Mulder, L.B. and Van Lange, P.A.M. (2011). 'Reward, punishment, and cooperation: A meta-analysis', Psychological Bulletin, Vol. 137: 594-615.

Becker, G.S. (1974). 'Crime and punishment: An economic aproach', in G.S. Becker and W.M. Landes (eds.), Essays in the Economics of Crime and Punishment (New York: National Bureau of Economic Research, 1974, 1-54).

Block, M.K. and Vernon, G.E. (1995). 'Some Experimental Evidence on Differences between Student and Prisoner Reactions to Monetary Penalties and Risk', The Journal of Legal Studies, Vol. 24: 123-138.

Caliendo, M. (2006). Microeconometric Evaluation of Labour Market Policies (Berlin: Springer-Verlag).

Camerer, C. (2011). 'The promise and success of lab-field generalizability in experimental economics: A critical reply to Levitt and List', Working Paper 1977749, (Los Angeles: Social Science Research Network).

Camerer, C., Babcock, L., Loewenstein, G. and Thaler, R. (1997). 'Labor Supply of New York City Cabdrivers: One Day at a Time', The Quarterly Journal of Economics, Vol. 112: 407441.

Fairhurst, T., and McLaughlin, D. (2009). 'Sustainalbe Oil Palm Development on Degraded Land in Kalimantan', (Washington, DC: World Wildlife Fund).

FAO. (2005). 'Fertilizer use by crop in Indonesia', First version (Rome: Food and Agriculture Organization of the United Nations (FAO)).

FAOSTAT. (2013). Data About Crop Production. Available at: http://faostat3.fao.org/faostatgateway/go/to/download/Q/*/E, (Rome: Food and Agricultural Organization of the United Nations. Statistics Division (FAOSTAT), last accessed 18 October 2013).

FAOSTAT. (2015). Data About Crop Production. Available at: http://faostat3.fao.org/download/O/OA/E, (Rome: Food and Agricultural Organization of the United Nations. Statistics Division (FAOSTAT), last accessed 28 April 2015).

Fehr, E. and Gächter, S. (2000). 'Cooperation and punishment in public goods experiments', American Economic Review, Vol. 90: 980-994.

Fehr, E. and Goette, L. (2007). 'Do Workers Work More if Wages Are High? Evidence from a Randomized Field Experiment', The American Economic Review, Vol. 97: 298-317.

Fehr, E., and Schmidt, K.M. (1999) 'A theory of fairness, competition, and cooperation', Quarterly Journal of Economics, Vol. 114: 817-868.

Fitzherbert, E.B., Struebig, M.J., Morel, A., Danielsen, F., Brühl, C.A., Donald, P.F. and Phalan, B. (2008). 'How will oil palm expansion affect biodiversity?', Trends in ecology \& evolution, Vol. 23: 538-545. 
Gächter, S., Renner, E. and Sefton, M. (2008). 'The long-run benefits of punishment', Science, Vol. 322: 1510.

Harrison, G.W. and List, J.A. (2004). 'Field experiments', Journal of Economic Literature, Vol. 42: 1009-1055.

Heath, C., Larrick, R.P. and Wu, G. (1999). 'Goals as Reference Points', Cognitive Psychology, Vol. 38: 79-109.

Herrmann, B., Thöni, C. and Gächter, S. (2008). 'Antisocial punishment across societies', Science, Vol. 319: 1362-1367.

Hewitt, C.N., MacKenzie, A.R., Di Carlo, P., Di Marco, C.F., Dorsey, J.R., Evans, M., Fowler, D., Gallagher, M.W., Hopkins, J.R., Jones, C.E., Langford, B., Lee, J.D., Lewis, A.C., Lim, S.F., McQuaid, J., Misztal, P., Moller, S.J., Monks, P.S., Nemitz, E., Oram, D.E., Owen, S.M., Phillips, G.J., Pugh, T.A.M., Pyle, J.A., Reeves, C.E., Ryder, J., Siong, J., Skiba, U. and Stewart, D.J. (2009). 'Nitrogen management is essential to prevent tropical oil palm plantations from causing ground-level ozone pollution', Proceedings of the National Academy of Sciences, Vol. 106: 18447-18451.

Ibanez, M. and Martinsson, P. (2008). 'Can we do policy recommendations from a framed field experiment? The case of coca cultivation in Colombia', Working Papers in Economics 306, (Gothenburg: University of Gothenburg. School of Business, Economics and Law).

Ihli, H.J. and Musshoff, O. (2013) 'Investment Behavior of Ugandan Smallholder Farmers: An Experimental Analysis', GlobalFood Discussion Papers 21, (Göttingen: University Göttingen).

Indexmundi. (2014). Palm oil montly price. Available at: http://www.indexmundi.com/commodities/?commodity=palm-oil\&-months=120 (Indexmundi.com, last accessed 28 November 2014).

Jelsma, I., Giller, K. and Fairhust, T. (2009) 'Smallholder Oil Palm Production Systems in Indonesia: Lessons from the NESP Ophir Project', (Wageningen: Wageningen University).

Kahneman, D. (2011). Thinking, Fast and Slow (New York: Farrar, Straus and Giroux).

Keller, M. and Matson, P.A. (1994). 'Biosphere-Atmosphere Exchange of Trace Gases in the Tropics: Evaluating the Effects of Land Use Changes', Global Atmospheric-Biospheric Chemistry, Vol. 48: 103-117.

Koh, L.P. and Wilcove, D.S. (2008). 'Is oil palm agriculture really destroying tropical biodiversity?', Conservation Letters, Vol. 1: 60-64.

Laumonier, Y., Uryu, Y., Stüwe, M., Budiman, A., Setiabudi, B. and Hadian, O. (2010). 'Ecofloristic sectors and deforestation threats in Sumatra: identifying new conservation area network priorities for ecosystem-based land use planning', Biodiversity and conservation, Vol. 19: 1153-1174.

Levitt, S. and List, J. (2007). 'What Do Laboratory Experiments Measuring Social Preferences Reveal about the Real World?', The Journal of Economic Perspectives, Vol. 21: 153-174. 
Palm, C.A., Alegre, J.C., Arevalo, L., Mutuo, P.K., Mosier, A.R. and Coe, R. (2002). 'Nitrous oxide and methane fluxes in six different land use systems in the Peruvian Amazon', Global Biogeochemical Cycles, Vol. 16: 1-21.

Poitras, G. (1998). 'Spread options, exchange options, and arithmetic Brownian motion', Journal of Futures Markets, Vol. 18: 487-517.

Polinsky, A.M. and Shavell, S. (1999). 'The economic theory of public enforcement of law', Working paper 6993, (Cambridge: National Bureau of Economic Research).

Pope, D.G. and Schweitzer, M. (2011). 'Is Tiger Woods loss averse? Persistent bias in the face of experience, competition, and high stakes', The American Economic Review, Vol. 101: 129-157.

Rand, D.G., Dreber, A., Ellingsen, T., Fudenberg, D. and Nowak, M.A. (2009). 'Positive interactions promote public cooperation', Science, Vol. 325: 1272-1275.

Reijnders, L. and Huijbregts, M.A.J. (2008). 'Palm oil and the emission of carbon-based greenhouse gases', Journal of Cleaner Production, Vol. 16: 477-482.

Sefton, M., Shupp, R. and Walker, J.M. (2007). 'The effect of rewards and sanctions in provision of public goods', Economic Inquiry, Vol. 45: 671-690.

Sekhon, G.S. (1995). 'Fertilizer-N use efficiency and nitrate pollution of groundwater in developing countries', Journal of Contaminant Hydrology, Vol. 20: 167-184.

Sutter, M., Haigner, S. and Kocher, M.G. (2010). 'Choosing the Carrot or the Stick? Endogenous Institutional Choice in Social Dilemma Situations', Review of Economic Studies, Vol. 77: 1540-1566.

Tiedemann, T. and Latacz-Lohmann, U. (2013). 'Production Risk and Technical Efficiency in Organic and Conventional Agriculture - The Case of Arable Farms in Germany', Journal of Agricultural Economics, Vol. 64: 73-96.

UNCTAD. (2013). Infocomm-AAACP Products-Palm Oil. Available at: http://www.unctad.info/en/Infocomm/AACP-Products/Palm-oil (Geneva: UNCTAD, last accessed 21 October 2013).

Veetil, V. (2011). 'Conceptions of rationality in law and economics', European Journal of Law and Economics, Vol. 31: 199-228.

Veldkamp, E. and Keller, M. (1997). 'Nitrogen oxide emissions from a banana plantation in the humid tropics', Journal of Geophysical Research: Atmospheres, Vol. 102: 1588915898.

Veldkamp, E., Purbopuspito, J., Corre, M.D., Brumme, R. and Murdiyarso, D. (2008). 'Land use change effects on trace gas fluxes in the forest margins of Central Sulawesi, Indonesia', Journal of Geophysical Research: Biogeosciences,: Vol. 113: 1-11.

Viceisza, A. (2012). Treating the field as a lab: A basic guide to conducting economics (Washington, DC: International Food Policy Research Institute (IFPRI)).

Volpp, K.G., John, L.K., Troxel, A.B., Norton, L., Fassbender, J. and Loewenstein, G. (2008). 'Financial incentive-based approaches for weight loss', JAMA, Vol. 300: 2631-2637. 
Chapter II: Ex ante evaluation of policy measures: Effects of reward and punishment for fertiliser reduction in palm oil production

Wilcove, D.S. and Koh, L.P. (2010). 'Addressing the threats to biodiversity from oil-palm agriculture', Biodiversity and conservation, Vol. 19: 999-1007.

Xe. (2014). Online Currency Converter-exchange rate from 15 August 2012. Available at: http://www.xe.com/currencytables (Newmarket: Xe.com, last accessed 28 November 2014). 


\title{
III. Comparing the use of risk-influencing production inputs and experimentally measured risk attitude: Do decisions of Indonesian small-scale rubber farmers match?
}

\section{Authors: Stefan Moser and Oliver Mußhoff}

Previous version published in: EFFoTS Discussion paper series No. 14 (2015)

\begin{abstract}
This article compares the use of risk-increasing and risk-reducing production inputs with the experimentally measured risk attitudes of farmers. For this purpose, the Just-Pope production function indicates production inputs' influence on output risk and a Holt-Laury lottery is used to measure the producers' risk attitude. We test whether more risk averse farmers use more risk-reducing and less risk-increasing production inputs. Therefore, we apply a unique data set which includes 185 small-scale farmers on the island of Sumatra, Indonesia. The Just-Pope production function indicates that a higher fertiliser usage has a risk-reducing effect, whereas a higher herbicide usage and a bigger plot size have riskincreasing effects. By including the outcome of a Holt-Laury lottery into the analysis, we found the expected result that more risk averse farmers use more (risk-reducing) fertiliser and less (risk-increasing) herbicides. These consistent results reinforces the external validity of measuring risk attitude with the Holt-Laury lottery.
\end{abstract}

\section{Keywords}

Holt-Laury lottery, Just-Pope production function, output risk, rubber, Indonesia

JEL classifications

C91, C93, Q12 


\section{Introduction}

Yield fluctuations caused by extreme weather conditions, diseases or the adoption of new technologies have the potential to lead to dramatic changes in income, thus making farming a risky business (Key and MacDonald, 2006). The output risk in combination with the risk attitudes of farmers are among the main drivers for production decisions in agriculture (Chavas et al., 2010). Moreover, Hellerstein et al. (2013) discuss the importance of understanding the risk attitude/production decision relationship since it helps to design policies which can accommodate changing economic and environmental circumstances as well as it supports farmers to make appropriate reactions. However, the precise manner in which risk and risk attitude affect farmer's production decisions is not easy to determine (Just, 2001; Just and Pope, 2003).

Analysing output risk as well as risk attitude is a primary focus in the research field pertaining to risk in agriculture (Chavas et al., 2010). An often applied and well-accepted method to investigate in output risk, i.e., output variance, in agricultural production is developed by Just and Pope (1978; 1979). This method shows production inputs' simultaneous influence on the output level and output risk in agricultural production systems. Several studies have applied and extended this approach for different contexts and purposes, thus proving its relevance (Chavas and Holt, 1996; Bar-Shira et al., 1997; Kumbhakar, 2001; 2002a; 2002b; Abdulkadri, 2003; Isik and Khanna, 2003; Kumbhakar and Tveterås, 2003; Barrett et al., 2004; Di Falco and Chavas, 2009; Gardebroek et al., 2010; Tiedemann and Latacz-Lohmann, 2013). Concerning the risk attitude, a long proven method for measuring it is through experiments (Binswanger, 1980). Moreover, Holt and Laury (2002) developed a well-accepted method to measure the risk attitude (Anderson and Mellor, 2008). Ihli and Musshoff (2013) further adapted this Holt-Laury (HL) risk measure to be applied to people with limited formal education. By taking this adaptation into consideration, we can apply this method for measuring risk attitudes in rural areas of developing countries.

In the literature, a discussion regarding the external validity (sometimes termed generalisability) of experimentally obtained results is in progress. We denote external validity of experimental results as "insights gained in the lab can be extrapolated to the world beyond" (Levitt and List, 2007: 153), thus, field behavior is defined as behavior that occurs outside of the laboratory. However, Levitt and List (2007) are sceptical about the external validity of experimentally obtained results. They argue that the lab differs 
systematically from most naturally occurring environments which yields to results that are not always generalisable. Conversely, Camerer (2011) argues that experimental results are externally valid if sufficient information is available. He states that "if many experimental and field data sets were combined, with sufficient variation among variables [...], a 'Lab' dummy variable would not be significant" (Camerer, 2011: 6). According to Roe and Just (2009), in economics there is typically a trade-off between the external and internal validity of results, with field data on the one end and lab data on the other end of the spectrum. They suggest alleviating this tension by applying field or natural experiments. However, various approaches to the problem of external validity of experimental results can be seen in the literature. Certainly, more examples which directly compare experimental results and field behaviour would be appealing.

Farmers' production decisions are a good option for measuring their behaviour towards output risk in the field because these decisions have a crucial influence on farmers' income and, thus, reflect a major risk in the lives of farmers. By comparing this field behaviour towards risk with an experimentally measured risk attitude, we can determine if results found in the experiment have external validity to the behaviour in the field. In other words, we test if the revealed risk attitude is consistent with the experimentally measured risk attitude.

Investigations comparing field decisions towards risk and experimentally measured risk attitudes have already been completed. Hellerstein et al. (2013) predict farming decisions related to diversified operations or to having crop insurance with a lottery-choice mechanism that measures farmers' risk attitude and found contradicting results between field and experimental decisions. Further examples where lottery choices are used to predict agricultural decisions which include risk are, e.g., crop diversification in Peru, where experimental results helped predicting field behaviour (Engle-Warnick et al., 2007); decisions towards coffee production in Uganda, where the stated risk attitude explained production decisions (Hill, 2009); or adoption habits with regards to genetically modified crops in the USA, where results show a small effect through risk aversion (Barham et al., 2014). With respect to non-agricultural decisions, Anderson and Mellor (2009) found consistent relationships between experimentally measured risk attitudes and decisions regarding health and safety. It seems that currently there is no definite answer to whether experimentally measured risk aversion is reflected in the field behaviour, which requires further investigations. Furthermore, experimentally measured risk attitude and production 
decisions towards risk, evaluated with a Just-Pope (JP) production function, have not been compared thus far. This is especially relevant, since influencing output risk with the input choice is a tool which practically every farmer can utilize. Thus, farmers can manage income risk, independent of the availability of other tools like insurance, production diversification or non-farm labour.

On the islands of Sumatra and West Kalimantan, $72 \%$ of the Indonesian rubber output is produced (Arifin, 2005). Rubber is a major crop trees and together with oil palm it generate the majority of farmers' income in the Jambi province on Sumatra. In this province, $52 \%$ of the workforce is employed in the agricultural sector and about the half of the cultivated land is used for rubber production, which usually is managed by small-scale farmers (Statistical Year Book of Estate Crops, 2012). This shows the economic relevance of rubber for the region. Therefore, income risk caused through output risk in rubber production is a crucial concern in this region.

The objective of this paper is to determine whether farmers' production decisions towards risk are consistent with the risk attitude measured in an experiment. We test this for the case of small-scale rubber farmers in Jambi province on Sumatra, Indonesia. To determine farmers' field behaviour towards risk, a JP production function is used to estimate the influence of production inputs on output risk (Just and Pope, 1978; 1979). Thus, the first hypothesis is "H1: The amount of used production inputs has an influence on output risk". To measure farmers' risk attitude, we apply an incentivised HL lottery (Holt and Laury, 2002) within an extra-laboratory experiment. According to Charness et al. (2013: 93), such experiments "have the same spirit as laboratory experiments, but are conducted in a nonstandard manner". These methods allow for comparing the HL risk measures with an overor underuse of production inputs. Through utilization of the JP production function, we can answer the second hypothesis, "H2: More risk-averse farmers use more risk-reducing and less risk-increasing inputs".

The present research contributes to the existing literature in several ways. First, it adds to the discussion regarding the external validity of experimental results to field behaviour (Levitt and List, 2007; Roe and Just, 2009; Camerer, 2011). We are the first that compare production decisions evaluated with a JP production function and risk attitude measured with an incentivised HL lottery. Second, in the research area production is focused on rubber and oil palm cultivation. Therefore, output risk of rubber production can cause high income risks for the farmers. Moreover, it is important to know how to manage risk in 
rubber, because this could raise its attractiveness in comparison to the less environmental friendly oil palm. Thus far, little is known about risk-influencing effects of production inputs in rubber production. However, a deeper understanding of how to influence output risk in rubber production is relevant for the farmers, as well as for society as a whole in the Jambi province.

The remainder of the paper is organised as follows: The methodology is explained in Section 2. Section 3 gives a description of the sample selection and the data, while Section 4 presents and discusses the results. Section 5 concludes.

\section{Methods}

To answer the hypotheses of this paper, we proceed as follows: In Section 2.1. we explain how we apply a JP production function to analyse the inputs' influence on output risk. In Section 2.2., we explain how we test whether inputs over- or underuses are correlated with farmers' risk attitude measured with a HL lottery and how we evaluate if more risk averse farmers use more risk-reducing and less risk-increasing production inputs.

\subsection{Procedure for estimating inputs' influence on output risk}

With the JP production function (Just and Pope, 1978; 1979), we want to determine the production inputs' influence on the output risk, i.e., output variance. The model used to determine this is:

$$
q_{p v}\left(x_{k p v}, \varepsilon_{p v}\right)=f\left(x_{k p v}\right)+\varepsilon_{p v} \sqrt{h\left(x_{k p v}\right)}
$$

where $q_{p v}$ represents the production output from plot $p$ in village $v . x_{k p v}$ represents the input $k$ of plot $p$ in village $v$. What is more, $f\left(x_{k p v}\right)$ is the function which determines the output level, whereas the function $\sqrt{h\left(x_{k p v}\right)}$ determines the inputs' influence on output risk, both influenced by the input variables $x_{k p v}$. Moreover, $\varepsilon_{p v}$ is a stochastic disturbance with an expected value of zero, along with a positive and constant variance.

The estimation strategy used in this study is based on Gardebroek et al. (2010). Following this direction, we define that $\varepsilon_{p v} \sqrt{h\left(x_{k p v}\right)}=u_{p v}$. Thus, Equation (1) can be rewritten as $q_{p v}\left(x_{k p v}\right)=f\left(x_{k p v}\right)+u_{p v}$, with $u_{p v}$ as a residual. This modification makes the function for 
the output level $f\left(x_{k p v}\right)$ feasible. We apply a quadratic specification since this allows for using zero-value input observations. Thus, $q_{p v}\left(x_{k p v}\right)=f\left(x_{k p v}\right)+u_{p v}$ is specified by:

$$
q_{p v}=\alpha_{0}+\alpha_{v}+\sum_{k=1}^{K} \alpha_{k} x_{k p v}+\frac{1}{2} \sum_{k=1}^{K} \sum_{j=1}^{K} \alpha_{k j} x_{k p v} x_{j p v}+u_{p v}
$$

The village specific effects on output level, e.g., through different soil or weather conditions, are captured by $\alpha_{v}$. Moreover, $\alpha_{k}$ and $\alpha_{k j}$ show the inputs' influence on output level. $K$ equals the number of applied input variables. $\alpha_{0}$ is the intercept. With a translog specification for $u_{p v}$, we can estimate inputs' influence on output variance. This translog risk function is given by:

$$
\begin{aligned}
\ln \left|u_{p v}\right|=\beta_{0}+ & \frac{1}{2}\left(\beta_{v}+\sum_{k=1}^{K} \beta_{k} \ln \left(x_{k p v}\right)+\frac{1}{2} \sum_{k=1}^{K} \sum_{j=1}^{K} \beta_{k j} \ln \left(x_{k p v}\right) \ln \left(x_{j p v}\right)\right. \\
& \left.+\sum_{m=1}^{M} \beta_{m} D_{m}\right)+w_{p v}
\end{aligned}
$$

In Equation (3), the dependent variable $\ln \left|u_{p v}\right|$ is derived from the logarithmic absolute value of the residual in Equation (2). $\beta_{v}$ covers village-specific fixed effects of production risk. Moreover, since all values are taken in the natural logarithm $l n$, the coefficients $\beta_{k}$ and $\beta_{k j}$ reflect the elasticities of the output variance for the specific input variable, i.e., the inputs' influence on output risk. Furthermore, we have zero-value observations for some of the input variables; thus, $M$ signifies the number of correction dummies which are necessary to estimate unbiased coefficients for such inputs. These dummies contain a value of one for each zero-value observation of the respective variable (Battese, 1997). Other researchers have also applied such a dummy variable technique when using a JP production function (Di Falco and Chavas, 2009). $\beta_{0}$ is the intercept and $w_{p v}$ is the error term. For more in-depth details concerning Equation (3), please refer to the relevant literature (Just and Pope, 1978; 1979; Gardebroek et al., 2010).

For this analysis, we are interested in the marginal risk that is created by each input. In a translog specification such an inputs' marginal effect on risk is calculated as follows (Pavelescu, 2011):

$$
\frac{\delta \ln \left|u_{p v}\right|}{\delta x_{k p v}}=\beta_{k}+2 \beta_{k k} \ln \left(x_{k p v}\right)+\sum_{j=1 \neq k}^{K} \beta_{k j} \ln \left(x_{j p v}\right) \quad k=1, \ldots, K
$$


Equation (4) shows the partial derivative of the output risk of an input $k . \beta_{k}, \beta_{k k}$ and $\beta_{k j}$ are coefficient from Equation (3). With Equation (4), we can calculate the risk-increasing or risk-reducing effect of an input for each observation.

To prove the reliability of the JP production function, we test for monotonicity assumption for the function which determines the output level, i.e., Equation (2). Thus, we test whether inputs' marginal influence on output level is positive. Therefore, we derive Equation (2) as follows:

$$
\frac{\delta q_{p v}}{\delta x_{k p v}}=\alpha_{k}+2 \alpha_{k k} x_{k p v}+\sum_{j=1 \neq k}^{K} \alpha_{k j} x_{j p v} \quad k=1, \ldots, K
$$

\subsection{Procedure for estimating the influence of experimentally measured risk attitude on over- or underuse of inputs}

To measure farmers' risk attitude, an HL lottery is conducted (Holt and Laury, 2002). The HL lottery, shown in Table 1, is comprised of ten paired lottery-choice decisions between option A and option B. Each option has two possible payouts for which the probabilities are systematically changed. Option A has a moderate payout-spread and is therefore the "safe choice", whereas option B has a high payout-spread making it the "risky choice". Ex post, one pair is randomly chosen and paid out to the participants. The lottery was adapted to take into consideration that at least some of the people in the rural areas of Sumatra have a limited formal education or may even be illiterate. Therefore, the experiment was designed by visualising probabilities with differently coloured balls instead of complicated numerical probabilities, which makes the experiment easily understandable (Ihli and Musshoff, 2013). The applied design is pictured in the appendix (Figure A1). 
Table 1. Payoffs of the HL lottery

\begin{tabular}{|c|c|c|c|}
\hline Choice & Option A & Option B & $\begin{array}{l}\text { Difference in the } \\
\text { expected payoff }\end{array}$ \\
\hline 1 & $\begin{array}{l}\text { With } 10 \% \text { price of } \operatorname{Rp} 4,000 \\
\text { With } 90 \% \text { price of } \operatorname{Rp} 3,200\end{array}$ & $\begin{array}{l}\text { With } 10 \% \text { price of } \operatorname{Rp} 7,600 \\
\text { With } 90 \% \text { price of } \operatorname{Rp} 200\end{array}$ & Rp 2,340 \\
\hline 2 & $\begin{array}{l}\text { With } 20 \% \text { price of } \operatorname{Rp} 4,000 \\
\text { With } 80 \% \text { price of } \operatorname{Rp} 3,200\end{array}$ & $\begin{array}{l}\text { With } 20 \% \text { price of } \operatorname{Rp} 7,600 \\
\text { With } 80 \% \text { price of } \operatorname{Rp} 200\end{array}$ & Rp 1,680 \\
\hline 3 & $\begin{array}{l}\text { With } 30 \% \text { price of } \operatorname{Rp} 4,000 \\
\text { With } 70 \% \text { price of } \operatorname{Rp} 3,200\end{array}$ & $\begin{array}{l}\text { With } 30 \% \text { price of } \operatorname{Rp} 7,600 \\
\text { With } 70 \% \text { price of } \operatorname{Rp} 200\end{array}$ & Rp 1,020 \\
\hline 4 & $\begin{array}{l}\text { With } 40 \% \text { price of } \operatorname{Rp} 4,000 \\
\text { With } 60 \% \text { price of } \operatorname{Rp} 3,200\end{array}$ & $\begin{array}{l}\text { With } 40 \% \text { price of } \operatorname{Rp} 7,600 \\
\text { With } 60 \% \text { price of } \operatorname{Rp} 200\end{array}$ & 360 \\
\hline 5 & $\begin{array}{l}\text { With } 50 \% \text { price of } \operatorname{Rp} 4,000 \\
\text { With } 50 \% \text { price of } \operatorname{Rp} 3,200\end{array}$ & $\begin{array}{l}\text { With } 50 \% \text { price of } \operatorname{Rp} 7,600 \\
\text { With } 50 \% \text { price of } \operatorname{Rp} 200\end{array}$ & $\mathrm{Rp} \quad-300$ \\
\hline 6 & $\begin{array}{l}\text { With } 60 \% \text { price of } \operatorname{Rp} 4,000 \\
\text { With } 40 \% \text { price of } \operatorname{Rp} 3,200\end{array}$ & $\begin{array}{l}\text { With } 60 \% \text { price of } \operatorname{Rp} 7,600 \\
\text { With } 40 \% \text { price of } \operatorname{Rp} 200\end{array}$ & Rp $\quad-960$ \\
\hline 7 & $\begin{array}{l}\text { With } 70 \% \text { price of } \operatorname{Rp} 4,000 \\
\text { With } 30 \% \text { price of } \operatorname{Rp} 3,200\end{array}$ & $\begin{array}{l}\text { With } 70 \% \text { price of } \operatorname{Rp} 7,600 \\
\text { With } 30 \% \text { price of } \operatorname{Rp} 200\end{array}$ & Rp -1,620 \\
\hline 8 & $\begin{array}{l}\text { With } 80 \% \text { price of } \operatorname{Rp} 4,000 \\
\text { With } 20 \% \text { price of } \operatorname{Rp} 3,200\end{array}$ & $\begin{array}{l}\text { With } 80 \% \text { price of } \operatorname{Rp} 7,600 \\
\text { With } 20 \% \text { price of } \operatorname{Rp} 200\end{array}$ & $\mathrm{Rp}-2,280$ \\
\hline 9 & $\begin{array}{l}\text { With } 90 \% \text { price of } \operatorname{Rp} 4,000 \\
\text { With } 10 \% \text { price of } \operatorname{Rp} 3,200\end{array}$ & $\begin{array}{l}\text { With } 90 \% \text { price of } \operatorname{Rp} 7,600 \\
\text { With } 10 \% \text { price of } \operatorname{Rp} 200\end{array}$ & $\mathrm{Rp}-2,940$ \\
\hline 10 & $\begin{array}{l}\text { With } 100 \% \text { price of } \operatorname{Rp} 4,000 \\
\text { With } 0 \% \text { price of } \operatorname{Rp} 3,200\end{array}$ & $\begin{array}{c}\text { With } 100 \% \text { price of } \operatorname{Rp} 7,600 \\
\text { With } 0 \% \text { price of } \operatorname{Rp} 200\end{array}$ & $\mathrm{Rp}-3,600$ \\
\hline
\end{tabular}

Notes: Rp = Indonesian rupiah.

Table 1 shows that as the probability for higher outcomes increases in the HL lottery, the expected payoff difference between option A and option B decreases; beginning with the $5^{\text {th }}$ pair of choices, the expected outcome differences become negative. Therefore, a perfect rational, profit maximising participant would switch from option $A$ to option $B$ with the $5^{\text {th }}$ choice. For the first choices, only a strongly risk seeking participant would choose option B, whereas for the final choices, only a strongly risk averse participant would choose option A.

Consistent behaviour would be established if the participant would never switch from option B to option A as they make decisions in the HL lottery. The number of option A choices, i.e., the safe choices, would then be the relevant value which indicates the risk attitude. Unfortunately, such consistent behaviour is not always observed in the HL lottery (Holt and Laury, 2002). In the literature, several methods have been established for managing inconsistent behaviour in the HL lottery. The first method, as discussed by Holt and Laury (2002), is to consider only observations with consistent behaviour for the analysis. The number of safe choices present among the consistent observations is then the respective measure; we will call this measure "HL-consistent". This measure has the 
disadvantage of losing the observations with inconsistent behaviour. Alternatively, Holt and Laury suggest using the total number of safe choices as a risk measure, independent of whether the choices are consistent; this measure will be called "HL-total". Another method which is also discussed in the literature is to consider only the observation at the first switching point from option A to option $B$, independent of whether the choices beyond this point are consistent (Masclet et al., 2009); this measure will be termed "HL-change". With all three of the HL-measures presented here, a higher value implies more risk averse behaviour. For robustness purposes we will apply all three mentioned HL-measures for this analysis.

In order to assess the over- or underuse of a certain input, we deduct the perfect rational, profit maximising input use $x_{k p v}^{*}$ from the real input use $x_{k p v}$. To calculate the profit maximising input use $x_{k p v}^{*}$, we have to start with the profit calculation, which is as follows:

$$
\pi_{p v}=q\left(x_{k p v}^{*}\right) p_{p v}-\sum_{k=1}^{K} x_{k p v}^{*} w_{k p v}
$$

In Equation (6), the profit $\pi_{p v}$ is calculated by multiplying output $q\left(x_{k p v}^{*}\right)$ with the product price $p_{p v}$ and deduct the input $x_{k p v}^{*}$ multiplied with an input price of $w_{k p v}$ to account for the input costs. By deviating this equation with respect to $x_{k p v}^{*}$ we get:

$$
0=\frac{\partial q\left(x_{k p v}^{*}\right)}{\partial x_{k p v}^{*}} p_{p v}-\frac{\partial \sum_{k=1}^{K} x_{k p v}^{*}}{\partial x_{k p v}^{*}} w_{k p v} \quad k=1, \ldots, K
$$

The derivation on the right side of the minus equals one. Thus, restructuring and implementing the production function, which is also shown in Equation (2), yields:

$$
\frac{w_{k p v}}{p_{p v}}=\frac{\partial\left(\alpha_{0}+\alpha_{v}+\sum_{k=1}^{K} \alpha_{k} x_{k p v}^{*}+\sum_{k=1}^{K} \sum_{j=1}^{K} \alpha_{k j} x_{k p v}^{*} x_{j p v}+u_{p v}\right)}{\partial x_{k p v}^{*}} \quad k=1, \ldots, K
$$

By derivation and restructuring of Equation (8) we finally find how to calculate the perfect rational, profit maximising input use $x_{k p v}^{*}$.

$$
x_{k p v}^{*}=\frac{\frac{w_{k p v}}{p_{p v}}-\alpha_{k}-\sum_{j=1 \neq k}^{K} \alpha_{k j} x_{j p v}}{2 \alpha_{k k}} \quad k=1, \ldots, K
$$

By applying the coefficients of the function for the output level (Equation (2)), we can calculate the values for $x_{k p v}^{*}$ for each input and observation. The difference between the real input use $x_{k p v}$ and the perfect rational, profit maximising input use $x_{k p v}^{*}$ is shown by $x_{k p v}^{\Delta}$ : 


$$
x_{k p v}^{\Delta}=x_{k p v}-x_{k p v}^{*}
$$

Thus, a positive or negative $x_{k p v}^{\Delta}$ identifies the over- or underuse of a certain input, respectively. With the values of $x_{k p v}^{\Delta}$ at hand, it is possible to test whether inputs over- or underuse correlates with producers' risk-aversion $H L_{p v}$ as follow:

$$
x_{k p v}^{\Delta}=\gamma_{0}+\gamma_{1} H L_{p v}+\gamma_{2}\left(H L_{p v}\right)^{2}+z_{k p v}
$$

$\gamma_{1}$ and $\gamma_{2}$ show the influence of the linear and the squared HL-measures on input' over-or underuse. $\gamma_{0}$ and $z_{k p v}$ are the intercept and the residual, respectively. For robustness purposes, all three discussed HL-measures for risk attitude, i.e., HL-consistent, HL-total and HL-change, are used as independent variables for a single variable quadratic function with $x_{k p v}^{\Delta}$ as the dependent variable. Therefore, we have three independent regressions for each input variable. By deriving Equation (11), we can calculate the marginal effect of the HLmeasures on input use:

$$
\frac{\partial x_{k p v}^{\Delta}}{\partial H L_{p v}}=\gamma_{1}+2 \gamma_{2} H L_{p v}
$$

Equation (12) determines the marginal effects of the respective HL-measure on the input use. Combined with the results from Section 2.1., we can demonstrate if more risk-averse farmers use more risk-reducing and less risk-increasing production inputs.

\section{Sample selection and data}

The data was collected in the Jambi Province on Sumatra, Indonesia. Jambi has approximately three million inhabitants and has an area of roughly 50,000 square kilometres. The research area extends over five regencies of the Jambi Province: Sarolangun, Tebo, Bungo, Batang Hari and Muaro Jambi. Rubber is a major tree crop in this area (Otsuka et al., 2000, Statistical Year Book of Estate Crops, 2012).

The data were collected from October to December 2012 in 35 randomly chosen villages. With one exception, 2 villages are always located in one district, resulting in 18 different districts. Depending on the size of each village, between 10 and 24 randomly chosen farmers were invited to participate in this research. Since not all farmers accepted the invitation, and not all farmers cultivate rubber, the final data set consists of 185 farmers, which cultivate a combined total of 260 rubber plots. In the used data set, a farmer may have several rubber plots, however, these plots are always within one village. While the production and 
socioeconomic data were collected a few days in advance, the experiments took place, depending on local conditions, in the early afternoon or after evening prayer. The experiments were conducted in available public spaces such as schools, gymnasiums or the house of the village head. Before the experiment began, participants had to sit separately from one another and were not allowed to speak, except with the enumerators. Each participant then received a questionnaire to fill-in with their experimental decision and an enumerator explained the instructions with the support of visual aids. In order to account for learning effects, the HL lottery was conducted twice. For the analysis, only the results of the second HL lottery were used. To avoid a consecutive execution of these HL lotteries, other experiments were included as an interruption. These experiments tested for, e.g., trust among the participants or dealt with ex ante testing of policy measures and had no direct connection to the HL lottery. To avoid disturbing influences from the first HL lottery or the other experiments on the second HL lottery, all earnings were evaluated after the decisions had been made.

Most participants won between $\mathrm{Rp} 40,000$ and $\mathrm{Rp}$ 60,000 for all experiments, which were then distributed in the form of a shopping voucher for a local shop. The two HL lotteries account for $\mathrm{Rp} \mathrm{8,336} \mathrm{of} \mathrm{these} \mathrm{sums} \mathrm{in} \mathrm{average.} \mathrm{Considering} \mathrm{that} \mathrm{the} \mathrm{average} \mathrm{daily} \mathrm{wage} \mathrm{for} \mathrm{a}$ worker is around $\mathrm{Rp} 50,000$ in the research area, the amount of vouchers seem to be adequate compensation for these experiments. The lotteries took about half an hour, whereas the other experiments took around three hours. 
Table 2. Socioeconomic, experimental and production data

\begin{tabular}{lcc}
\hline & mean & sd \\
\hline Observations rubber farmers & 185 & \\
Male, percent & 83.61 & \\
Age, years & 44.03 & 10.49 \\
Education, years & 7.67 & 3.12 \\
Household size, persons & 4.50 & 1.42 \\
First lottery, HL-consistent & 3.85 & 2.95 \\
Second lottery, HL-consistent & 3.95 & 2.72 \\
First lottery, HL-total & 4.39 & 2.42 \\
Second lottery, HL-total & 4.36 & 2.32 \\
First lottery, HL-change & 2.46 & 2.58 \\
Second lottery, HL-change & 2.64 & 2.56 \\
\hline Observations rubber plots & 260 & \\
Yield, kga) & 3,167 & 3,441 \\
Fertiliser, kga) & 78.2 & 224.8 \\
Herbicides, litre & 5.45 & 9.79 \\
Labour, hours/year & 964 & 612 \\
Plot size, hectare & 2.07 & 1.84 \\
Plantation age, years & 19.30 & 9.14 \\
\hline
\end{tabular}

Notes: a) Fertiliser and herbicides have 192 and 138 zero-value observation, respectively.

Table 2 shows the socioeconomic, experimental and production data of the relevant farmers and plots. For this analysis we apply five production inputs, i.e., fertiliser, herbicides, labour, plot size and plantation age. For fertilizer and herbicides, the high standard deviation in relation to mean values can be explained through the high share of zero-value observations. For each of the three HL measures, the differences between the first and the second lotteries are not significant at the $5 \%$ level.

\section{Results}

In the section 4.1, we show the estimated influence form production inputs on output risk. Thus, we can respond to the first hypotheses. Section 4.2 shows the correlation of the experimentally measured risk attitude and the input use. Together with results from 4.1, the second hypotheses is answered.

\subsection{Estimated inputs' influence on output risk}

Following the estimation strategy described in Section 2.1, the JP production function starts with estimating inputs' influence on output level with the quadratic production function, described in Equation (2). Therefore, we account for five production inputs, i.e., fertiliser, 
herbicides, labour, plot size and plantation age. We assume that output variance is related to input use, which implies heteroskedasticity. Therefore, we apply White's procedure in order to obtain heteroskedasticity robust standard errors (Wooldridge, 2002). The results of this estimation can be seen in Table A1 in the appendix. Seven out of the twenty estimated coefficients are significantly different from zero at a $10 \%$ level. An F-test clearly indicates the existence of unobserved, village constant effects. Moreover, the adjusted R-square of 0.617 indicates a high degree of explanatory power of the estimated production function.

For each input of this quadratic production function, we tested whether the monotonicity assumption is violated. Therefore, we calculated the marginal influence on output level for each production input (Equation (3)). In 25 of the 68 observations where fertilizer is used, monotonicity is violated. However, if we split those 68 observations into herbicide users and non-herbicide users, we find that fertiliser users which also use herbicide violate monotonicity at a higher level of $44.2 \%$ (23/52 observations), whereas fertilizer users that do not also use herbicide do this only at a reasonable level of 12.5\% (2/16 observations). For herbicide, 47 out of 122 observations where herbicide is used violate the assumption of monotonicity. However, if we split these 122 observations up into fertiliser users and nonfertiliser users, we find that $67.3 \%$ (35/52) and $17.1 \%$ (12/70) violate monotonicity, respectively. For the majority of the 52 plots where the use of fertilizer and herbicides is combined, monotonicity is violated, whereas for the other plots the monotonicity assumption for fertiliser and herbicide is fulfilled at a reasonable level. Through further investigation, we found that those 52 plots have on average $72.8 \mathrm{~kg}$ more yield per hectare and also a $2.5 \%$ higher product price. Even though these differences are not significant, farmers seem to have an advantage in using both of these inputs, even though the violation of monotonicity indicates an overuse of these inputs in many cases. However, for labour and plot size, we found that monotonicity was violated at a reasonable level in 3.5\% (9/260) and $10.4 \%(27 / 260)$ of the observations, respectively. Since we do not expect yields to increase with plantation age, the violation in $39.2 \%(102 / 260)$ of the observations is unproblematic for this production input. To summarize, aside from the observations where fertiliser and herbicide are used simultaneously, monotonicity is fulfilled to a reasonable degree. Therefore, it is apparent that we have a well-specified production function.

To estimate inputs' influence on output risk, we apply the translog risk function shown in Equation (3). By including fixed effects, we account for village constant, risk influencing effects. In order to obtain unbiased results, we introduced three correction dummies: one 
for fertiliser, one for herbicides and due to the significant interaction found between fertilizer and herbicide usage in the discussion about monotonicity, we additionally introduce a correction dummy for observations with non-zero values of fertilizer and herbicides (Battese, 1997). As demanded by the model, all variables are applied in logarithmic values (Just and Pope 1978; 1979). The results of this estimation can be seen in Table 3.

Table 3. Elasticities of input use on output risk

\begin{tabular}{|c|c|c|c|c|}
\hline & mean & se & p-value & \\
\hline Fertiliser & 0.636 & 2.223 & 0.775 & \\
\hline Herbicides & -1.073 & 1.759 & 0.542 & \\
\hline Labour & 1.449 & 4.464 & 0.746 & \\
\hline Plot size & 5.902 & 3.676 & 0.110 & \\
\hline Plantation age & -0.635 & 6.362 & 0.921 & \\
\hline Fertiliser $\mathrm{x}$ Fertiliser & -0.021 & 0.095 & 0.827 & \\
\hline Fertiliser $\mathrm{x}$ Herbicides & -0.006 & 0.018 & 0.725 & \\
\hline Fertiliser x Labour & -0.045 & 0.037 & 0.219 & \\
\hline Fertiliser x Plot size & 0.037 & 0.032 & 0.247 & \\
\hline Fertiliser x Plantation age & 0.002 & 0.030 & 0.933 & \\
\hline Herbicides x Herbicides & 0.016 & 0.097 & 0.872 & \\
\hline Herbicides x Labour & 0.132 & 0.038 & 0.001 & $* * *$ \\
\hline Herbicides x Plot size & -0.103 & 0.036 & 0.004 & $* * *$ \\
\hline Herbicides x Plantation age & -0.012 & 0.038 & 0.747 & \\
\hline Labour x Labour & -0.168 & 0.164 & 0.308 & \\
\hline Labour x Plot size & -0.052 & 0.268 & 0.846 & \\
\hline Labour x Plantation age & 0.298 & 0.289 & 0.304 & \\
\hline Plot size x Plot size & 0.143 & 0.141 & 0.309 & \\
\hline Plot size $\mathrm{x}$ Plantation age & -0.672 & 0.261 & 0.011 & $* *$ \\
\hline Plantation age $\mathrm{x}$ Plantation age & 0.083 & 0.261 & 0.750 & \\
\hline Dummy fertiliser & 0.396 & 13.275 & 0.976 & \\
\hline Dummy herbicides & -0.566 & 8.024 & 0.944 & \\
\hline Dummy fertiliser $x$ Dummy herbicides & 0.281 & 1.974 & 0.887 & \\
\hline Constant & -21.38 & 44.97 & 0.635 & \\
\hline Observations & 260 & & & \\
\hline Adjusted R-square & 0.623 & & & \\
\hline
\end{tabular}

Notes: Significantly different from zero at the ${ }^{* * 5 \%}$ and ${ }^{* * *} 1 \%$ levels.

In Table 3, from the 20 variables which are not correction dummies, 3 are significantly different from zero at a $5 \%$ level. This low share of significant influences for such regressions can also be found in other studies, e.g., 4 out of 35 (Gardebroek et al., 2010). However, the high adjusted R-square of 0.623 indicates a high explanatory power of the output risk with the used inputs. Therefore, this regression seems to be a good basis for the 
further analysis. An F-test indicates the existence of unobserved, village constant effects on the output risk. By further investigating these effects, we found that approximately $10.8 \%$ of the variation between villages can be explained with regency variables. Thus, the southwestern regency, Sarolangun, has the highest output risk, whereas the north-western Tebo and Bungo have medium output risk. The lowest output risk was found in Batang Hari, which is in the central region of the research area, followed by the eastern regency Muara Jambi. It can thus be determined that there are regional differences concerning the output risk.

With respect to the first hypothesis "H1: The amount of used production inputs has an influence on output risk" Table 3 shows that 3 out of 20 combinations of inputs have a significant influence on output risk. Therefore, we can support the first hypothesis.

To determine the inputs' marginal influence on output risk, we apply Equation (5). For fertiliser and herbicides, it is reasonable to consider only observations with non-zerovalues. For the purpose of this article, we are primarily interested in the direction, and not in the size, of an inputs' influence on output risk. To find such direction, we compare the number of risk-increasing and risk-reducing observations for each input. However, it is difficult to determine at which proportion of risk-increasing and risk-reducing observations an input's influence on output risk is distinct. In order to determine the direction of inputs' influence on output risk, we determined that it is sufficient if more than $75 \%$ of the observations point in the same direction.

Table 4. Marginal effects of inputs on output risk

\begin{tabular}{lcccc}
\hline Input & $\begin{array}{c}\text { Non-zero } \\
\text { observations }\end{array}$ & $\begin{array}{c}\text { Risk-increasing } \\
\text { observations }\end{array}$ & $\begin{array}{c}\text { Risk-decreasing } \\
\text { observations }\end{array}$ & $\begin{array}{c}\text { Inputs' influence } \\
\text { on risk }\end{array}$ \\
\hline Fertiliser & 68 & $0 \quad(0 \%)$ & $68(100 \%)$ & Risk-decreasing \\
Herbicides & 122 & $114(93 \%)$ & $8 \quad(7 \%)$ & Risk-increasing \\
Labour & 260 & $106(41 \%)$ & $154(59 \%)$ & Ambiguous \\
Plot size & 260 & $197(76 \%)$ & $63(24 \%)$ & Risk-increasing \\
Plantation age & 260 & $145(56 \%)$ & $115(44 \%)$ & Ambiguous \\
\hline
\end{tabular}

Table 4 shows that for all 68 non-zero observations, the marginal effect of fertiliser usage is risk-decreasing. Moreover, the marginal effect of herbicide usage is risk-increasing for a clear majority (93\%) of the non-zero-value observations. For plot size, we found a riskincreasing effect for $76 \%$ of the observations. Therefore, we consider this production input to also be risk-increasing. However, for labour and plantation age the observations of risk- 
increasing and risk-decreasing marginal effects are almost equal, making the influence on output risk ambiguous. Thus, to go further with the analysis only fertilizer, herbicides and plot size are taken into consideration.

\subsection{Influence of experimentally measured risk attitude on input use}

According to Equation (10), $x_{k p v}^{\Delta}$ indicates an over- or underuse of an input, respectively. For fertiliser, we found an overuse in 40 and an underuse in 28 observations. For herbicides, we found an over- or underuse in 74 and 48 observations, respectively. This relatively high share of overuse was already established for both of these inputs during the discussion about the monotonicity assumption. Unfortunately, for the plot size input, we have little information pertaining to land prices. Therefore, a reasonable calculation of $x_{k p v}^{\Delta}$ is not possible and we have to omit this input for the further analysis.

Table 5. Effect of HL-measures on fertiliser and herbicide over- or underuse $\left(x_{k p v}^{\Delta}\right)^{\mathrm{a})}$

\begin{tabular}{|c|c|c|c|c|c|c|}
\hline & \multicolumn{4}{|c|}{$\begin{array}{c}\text { Estimated influence of the respective } \\
\text { HL-measure on over- or underuse of } \\
\text { input } \\
\text { (Equation (11)) }\end{array}$} & \multicolumn{2}{|c|}{$\begin{array}{c}\text { Marginal effect of the respective HL- } \\
\text { measure on over- or underuse of input } \\
\text { (Equation (12)) }\end{array}$} \\
\hline & \multirow{3}{*}{ mean } & $\begin{array}{l}\text { linear } \\
\left(\gamma_{1}\right)\end{array}$ & \multicolumn{2}{|c|}{$\begin{array}{c}\text { squared } \\
\left(\gamma_{2}\right)\end{array}$} & \multirow{2}{*}{$\begin{array}{c}\begin{array}{c}\text { positiv marginal } \\
\text { effect }\end{array} \\
\frac{\partial q\left(x_{k p v}^{\Delta}\right)}{\partial H L_{k p v}}>0\end{array}$} & \multirow{2}{*}{$\begin{array}{c}\begin{array}{c}\text { negativ marginal } \\
\text { effect }\end{array} \\
\frac{\partial q\left(x_{k p v}^{\Delta}\right)}{\partial H L_{k p v}}<0\end{array}$} \\
\hline & & p-value & mean & p-value & & \\
\hline \multicolumn{6}{|l|}{$x_{k p v}^{\Delta}$ fertiliser } & \\
\hline$H L_{p v^{-}}$-consistentb) c) & -272.2 & $0.025^{* *}$ & 24.940 & $0.051^{*}$ & $\left.78.0 \% \quad 32 / 41^{d}\right)$ & $22.0 \% 9 / 41^{d)}$ \\
\hline 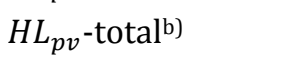 & -154.0 & 0.115 & 9.865 & 0.338 & $\left.85.3 \% \quad 58 / 68^{d}\right)$ & $14.7 \% \quad 10 / 68^{\mathrm{d})}$ \\
\hline 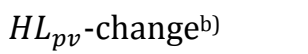 & -197.9 & $0.008^{* * *}$ & 19.25 & $0.036^{* *}$ & $55.9 \% \quad 38 / 68 \mathrm{~d})$ & $44.1 \% \quad 30 / 68 \mathrm{~d})$ \\
\hline \multicolumn{7}{|l|}{$x_{k p v}^{\Delta}$ herbicides } \\
\hline$H L_{p v^{-}}$-consistent ${ }^{\mathrm{b}) \mathrm{c}}$ & 4.510 & $0.034^{* *}$ & -0.629 & $0.017^{* *}$ & $16 / 75^{\mathrm{d})}$ & $78.7 \% \quad 59 / 75^{d)}$ \\
\hline 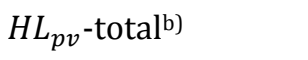 & 2.469 & 0.142 & -0.287 & 0.144 & $26 / 122^{d)}$ & $\left.78.7 \% \quad 96 / 122^{d}\right)$ \\
\hline$H L_{p v}$-change ${ }^{\mathrm{b})}$ & 3.484 & $0.021^{* *}$ & -0.516 & $0.011^{* *}$ & $36.9 \% \quad 45 / 122^{d)}$ & $\left.63.1 \% \quad 77 / 122^{d}\right)$ \\
\hline
\end{tabular}

Note: Significantly different from zero at the $* 10 \%, * * 5 \%$ and ${ }^{* * *} 1 \%$ levels. a) Estimating with fixed effects at the district level, as well as at the village level, results in qualitatively similar results, but in high losses of degrees of freedom. Moreover, estimating with the HL-measures from the first HL-lottery leads to similar results; b) Each line represents estimation results of one regression; c) Lost observations through inconsistency are 27 and 47 for fertiliser and herbicides, respectively; d) Share of observations with the respective marginal effect.

Table 5 shows the influence of the HL risk measures on over- or underuse of fertiliser and herbicides. Therefore, the regression results from Equation (11) regarding fertiliser and herbicides are presented, each with results for HL-consistent, HL-total and HL-change. A higher HL-measure indicates a farmer having a higher aversion to risk. Moreover, the respective marginal effect of these HL-measures on $x_{k p v}^{\Delta}$ is calculated (Equation (12)). 
Similar to Table 4 , the effect is determined to be definite if more than $75 \%$ of the observations point in one direction. Before interpreting Table 5 , it is necessary to recall that fertiliser was found to be risk-decreasing while herbicide was found to be risk-increasing (Table 4).

For the three regressions with $x_{k p v}^{\Delta}$ fertiliser as the dependent variable, we found that the coefficients of HL-consistent and HL-change are significant different from zero at 5\% or close to this level, which strongly indicates a relationship between these HL-measures and fertilizer use. For HL-total, no significant difference from zero is indicated. For HL-total and HL-consistent, more than $75 \%$ of the observations clearly indicate a positive marginal effect of these HL-measures on $x_{k p v}^{\Delta}$ fertiliser. Despite the ambiguous marginal effect for HLchange, we can clearly support the statement that more risk-averse farmers (indicated by higher HL-measures) use more (risk-decreasing) fertiliser. Thus, for the fertiliser input we find consistent results for input use and experimentally measured risk-aversion.

For $x_{k p v}^{\Delta}$ herbicides, we found a pattern similar to the outcome for fertilizer. Whereas the coefficients of HL-total are not significantly different from zero, the coefficients of HLconsistent and HL-change are significant at 5\% level. This clearly indicates a relationship between the latter two HL-measures and $x_{k p v}^{\Delta}$ herbicides. For HL-consistent and HL-total, a negative marginal effect on herbicides use for more than $75 \%$ of the observations can be seen. For HL-change, with a share of $63.1 \%$, the marginal effect is ambiguous. Overall, results slightly indicate that more risk-averse farmers use less (risk increasing) herbicide. This indicates consistent results for herbicides use and experimentally measured riskaversion.

With respect to the second hypothesis "H2: More risk-averse farmers use more riskdecreasing and less risk-increasing inputs", we find that more risk averse farmers use more (risk-decreasing) fertilizer and less (risk-increasing) herbicides. Consequently, we support hypothesis two. It seems that participants' field behaviour towards risk and their experimentally measured risk attitude are consistent considering the example of using riskinfluencing production inputs. In other words, for the context of this article results indicate the experimentally measured risk attitude has external validity for the behaviour in the field. 


\section{Conclusions}

Production output in agriculture can vary significantly, making farming a risky business. Literature indicates that such output risks can be influenced by the choice of production inputs. However, these output risks combined with farmers' risk attitudes, influence farmers' production decisions. Having a better understanding of farmers' risk attitude can help with better understanding farmers' production decisions, especially with respect to output risk and, thus, in better dealing with changing circumstances. This is relevant for the individual farmers, as well as for the development of proper policy measures. This research is done for the case of rubber farmers on Sumatra, which is an important region for rubber production in Indonesia. The output risk of rubber is especially relevant for the research area, since in large parts of the area rubber is the main tree crop and therefore plays a major role in income generation for farmers.

To investigate the research hypotheses, i.e., "H1: The amount of used production inputs has an influence on output risk" and "H2: More risk-averse farmers use more risk-reducing and less risk-increasing inputs", a JP production function was conducted to determine inputs' influence on output risk. Furthermore, a HL lottery was used to experimentally measure farmers' risk attitudes. We find that fertiliser is a risk-decreasing input, whereas herbicides and plot size are risk-increasing production inputs. For labour and plantation age, the influences on output risk are ambiguous. In accordance with our expectations, we found that more risk averse farmers use more (risk-decreasing) fertiliser and less (risk-increasing) herbicides. These results indicate that the use of inputs, with respect to inputs' influence on output risk, and the experimentally measured risk attitude are consistent, which implies external validity of the experimentally measured risk attitude.

In the literature, the relationship between field behaviour towards risk and experimentally measured risk attitude is unclear. Some articles show no significant or inconsistent correlations of field behaviour and experimentally measured risk attitude, (e.g., Anderson and Mellor, 2009; Hellerstein et al., 2013; Barham et al., 2014), while other articles indicate consistent correlations (e.g., Engle-Warnick et al., 2007; Hill, 2009). With the article at hand we contribute to this controversial discussion. However, this discussion demands for further contributions. Applying the method in this article to other crops, an evaluation of a farm as a whole, or to other countries could further strengthen the found results. Moreover, extending the method to a panel data set could account for possible changes over time which would further support the discussion of external validity of experimental results. Additionally, 
Lence (2009) discuss difficulties of insufficiently estimating the risk aversion in combination with a JP production function. In this context, it could be interesting to compare the estimated with the measured risk attitude.

The results of this article are relevant for several reasons. First, by comparing the results of a JP production function and risk attitude measured with an incentivised HL lottery, we add this example to the literature for testing the external validity of such experimental results. This is relevant because influencing output risk with the input choice is something that can be done by a vast majority of farmer. Second, we found significant influence from fertiliser and herbicides usage on output risk for rubber production in the research area. Moreover, the use of these inputs goes along with farmer risk attitude. This knowledge can help with managing such risks and provides important information for farmers, as well as for policy makers. The massive expansion of oil palm plantations in the research area causes considerable negative externalities (Koh and Wilcove, 2008; Laumonier et al., 2010; Wilcove and Koh, 2010). Since in this region rubber is the obvious alternative to oil palm, increasing the attractiveness of rubber by knowing how to handle output risk may lead to a conversion to this fruit, which would reduce the mentioned negative externalities. 


\section{References}

Abdulkadri, A.O. (2003). 'Estimating risk aversion coefficients for dry land wheat, irrigated corn and dairy producers in Kansas', Applied Economics, Vol. 35: 825-834.

Anderson, L.R. and Mellor, J.M. (2008). 'Predicting health behaviors with an experimental measure of risk preference', Journal of health economics, Vol. 27: 1260-1274.

Anderson, L.R. and Mellor, J.M. (2009). 'Are risk preferences stable? Comparing an experimental measure with a validated survey-based measure', Journal of Risk and Uncertainty, Vol. 39: 137-160.

Arifin, B. (2005). 'Supply Chain of Natural Rubber in Indonesia' Jurnal Manajemen Dan Agribisnis, Vol 2: 1-16.

Barham, B., Chavas, J.P., Fitz, D., Rios Salas, V. and Schechter, L. (2014). 'The roles of risk and ambiguity in technology adoption', Journal of Economic Behavior and Organization, Vol. 97: 204-218.

Bar-Shira, Z., Just, R.E. and Zilberman, D. (1997). 'Estimation of farmers' risk attitude: an econometric approach', Agricultural Economics, Vol. 17: 211-222.

Barrett, C.B., Moser, C.M., McHugh, O.V. and Barison, J. (2004). 'Better technology, better plots, or better farmers? Identifying changes in productivity and risk among Malagasy rice farmers', American Journal of Agricultural Economics, Vol. 86: 869-888.

Battese, G.E. (1997). 'A note on the estimation of Cobb-Douglas production functions when some explanatory variables have zero values', Journal of Agricultural Economics, Vol. 48: $250-252$.

Binswanger, H.P. (1980). 'Attitudes toward risk: Experimental measurement in rural India', American Journal of Agricultural Economics, Vol. 62: 395-407.

Camerer, C. (2011). 'The promise and success of lab-field generalizability in experimental economics: A critical reply to Levitt and List', Working Paper 1977749, (Los Angeles: Social Science Research Network).

Charness, G., Gneezy, U., and Kuhn, M.A. (2013). 'Experimental methods: Extra-laboratory experiments-extending the reach of experimental economics', Journal of Economic Behavior \& Organization, Vol. 91: 93-100.

Chavas, J.P., Chambers, R.G. and Pope, R.D. (2010). 'Production economics and farm management: a century of contributions', American Journal of Agricultural Economics, Vol. 92: 356-375.

Chavas, J.P. and Holt, M.T. (1996). 'Economic behavior under uncertainty: A joint analysis of risk preferences and technology', The Review of Economics and Statistics, Vol. 78: 329335.

Di Falco, S. and Chavas, J.P. (2009). 'On crop biodiversity, risk exposure, and food security in the highlands of Ethiopia', American Journal of Agricultural Economics, Vol. 91: 599611. 
Engle-Warnick, J., Escobal, J. and Laszlo, S. (2007). 'Ambiguity aversion as a predictor of technology choice: experimental evidence from Peru', Working Paper 2007s-01, (Montreal: Social Science Research Network).

Gardebroek, C., Chavez, M.D. and Lansink, A.O. (2010). 'Analysing production technology and risk in organic and conventional Dutch arable farming using panel data', Journal of Agricultural Economics, Vol. 61: 60-75.

Hellerstein, D., Higgins, N. and Horowitz, J. (2013). 'The predictive power of risk preference measures for farming decisions', European Review of Agricultural Economics, Vol. 40: 807-833.

Hill, V.R. (2009). 'Using stated preferences and beliefs to identify the impact of risk on poor households', The Journal of Development Studies, Vol. 45: 151-171.

Holt, C.A. and Laury, S.K. (2002). 'Risk aversion and incentive effects', American economic review, Vol. 92: 1644-1655.

Ihli, H.J. and Musshoff, O. (2013) 'Investment Behavior of Ugandan Smallholder Farmers: An Experimental Analysis', GlobalFood Discussion Papers 21, (Göttingen: University Göttingen).

Isik, M. and Khanna, M. (2003). 'Stochastic technology, risk preferences, and adoption of site-specific technologies', American Journal of Agricultural Economics, Vol. 85: 305317.

Just, R.E. (2001). 'Addressing the changing nature of uncertainty in agriculture', American Journal of Agricultural Economics, Vol. 83: 1131-1153.

Just, R.E. and Pope, R.D. (1978). 'Stochastic specification of production functions and economic implications', Journal of Econometrics, Vol. 7: 67-86.

Just, R.E. and Pope, R.D. (1979). 'Production function estimation and related risk considerations', American Journal of Agricultural Economics, Vol. 61: 276-284.

Just, R.E. and Pope, R.D. (2003). 'Agricultural risk analysis: adequacy of models, data, and issues', American Journal of Agricultural Economics, Vol. 85: 1249-1256.

Key, N.D. and MacDonald, J.M. (2006). 'Agricultural Contracting Trading Autonomy for Risk Reduction', Amber Waves, Vol. 4: 26-31.

Koh, L.P. and Wilcove, D.S. (2008). 'Is oil palm agriculture really destroying tropical biodiversity?', Conservation letters, Vol. 1: 60-64.

Kumbhakar, S.C. (2001). 'Risk preferences under price uncertainties and production risk', Communications in Statistics-Theory and Methods, Vol. 30: 1715-1735.

Kumbhakar, S.C. (2002a). 'Risk preference and productivity measurement under output price uncertainty', Empirical Economics, Vol. 27: 461-472.

Kumbhakar, S.C. (2002b). 'Specification and estimation of production risk, risk preferences and technical efficiency', American Journal of Agricultural Economics, Vol. 84: 8-22. 
Kumbhakar, S.C. and Tveterås, R. (2003). 'Risk preferences, production risk and firm heterogeneity', The Scandinavian Journal of Economics, Vol. 105: 275-293.

Laumonier, Y., Uryu, Y., Stüwe, M.B.A., Setiabudi, B. and Hadian, O. (2010). 'Eco-floristic sectors and deforestation threats in Sumatra: identifying new conservation area network priorities for ecosystem-based land use planning', Biodiversity and Conservation, Vol. 19: 1153-1174.

Lence, S.H. (2009). 'Joint estimation of risk preferences and technology: flexible utility or futility?', American Journal of Agricultural Economics, Vol. 91: 581-598.

Levitt, S.D. and List, J.A. (2007). 'What do laboratory experiments measuring social preferences reveal about the real world?', The Journal of Economic Perspectives, Vol. 21: $153-174$.

Masclet, D., Colombier, N., Denant-Boemont, L. and Loheac, Y. (2009). 'Group and individual risk preferences: A lottery-choice experiment with self-employed and salaried workers', Journal of Economic Behavior \& Organization, Vol. 70: 470-484.

Otsuka, K., Suyanto, S., Sonobe, T. and Tomich, T.P. (2000). 'Evolution of land tenure institutions and development of agroforestry: evidence from customary land areas of Sumatra', Agricultural Economics, Vol. 25: 85-101.

Pavelescu, F.M. (2011). 'Some aspects of the translog production function estimation', Romanian Journal of Economics, Vol. 32: 131-150.

Roe, B.E. and Just, D.R. (2009). 'Internal and external validity in economics research: Tradeoffs between experiments, field experiments, natural experiments, and field data', American Journal of Agricultural Economics, Vol. 91: 1266-1271.

Statistical Year Book of Estate Crops. (2012). (Jambi Province: Estate Cop Services of Jambi Province).

Tiedemann, T. and Latacz-Lohmann, U. (2013). 'Production risk and technical efficiency in organic and conventional agriculture-the case of arable farms in Germany', Journal of Agricultural Economics, Vol. 64: 73-96

Wilcove, D.S. and Koh, L.P. (2010). 'Addressing the threats to biodiversity from oil-palm agriculture', Biodiversity and Conservation, Vol. 19: 999-1007.

Wooldridge, J. M. (2002). Econometric Analysis of Cross Sectional and Panel Data (Cambridge: MIT Press). 
Chapter III: Comparing the use of risk-influencing production inputs and experimentally measured risk attitde

\section{Appendix}

Table A1. Quadratic production function in levels

\begin{tabular}{|c|c|c|c|}
\hline & mean & $\mathbf{s e}^{\mathrm{a})}$ & p-value \\
\hline Fertilizer & -1.790 & 2.401 & 0.461 \\
\hline Herbicides & 85.609 & 58.363 & 0.152 \\
\hline Labour & 1.426 & 1.034 & 0.177 \\
\hline Plot size & 353.718 & 514.561 & 0.496 \\
\hline Plantation age & 114.081 & 74.687 & 0.136 \\
\hline Fertilizer x Fertilizer & 0.006 & 0.002 & $0.003^{* * *}$ \\
\hline Fertilizer x Herbicides & -0.613 & 0.136 & $0.000^{* * *}$ \\
\hline Fertilizer x Labour & -0.003 & 0.001 & $0.073^{*}$ \\
\hline Fertilizer x Plot size & 0.711 & 0.561 & 0.214 \\
\hline Fertilizer x Plantation age & 0.350 & 0.168 & $0.044^{* *}$ \\
\hline Herbicides x Herbicides & 6.621 & 1.330 & $0.000^{* * *}$ \\
\hline Herbicides x Labour & 0.045 & 0.065 & 0.494 \\
\hline Herbicides x Plot size & -39.571 & 22.705 & $0.090^{*}$ \\
\hline Herbicides x Plantation age & -5.764 & 3.506 & 0.109 \\
\hline Labour x Labour & 0.000 & 0.001 & 0.602 \\
\hline Labour x Plot size & -0.051 & 0.312 & 0.872 \\
\hline Labour x Plantation age & -0.037 & 0.061 & 0.545 \\
\hline Plot size x Plot size & -14.006 & 14.201 & 0.331 \\
\hline Plot size x Plantation age & 152.995 & 41.215 & $0.001^{* * *}$ \\
\hline Plantation age $\mathrm{x}$ Plantation age & -1.157 & 0.983 & 0.248 \\
\hline Constant & -868.405 & 1066.931 & 0.421 \\
\hline Observations & 260 & & \\
\hline Adjusted R-square & 0.617 & & \\
\hline
\end{tabular}


Chapter III:Comparing the use of risk-influencing production inputs and experimentally measured risk attitude: Do decisions of Indonesian smallscale rubber farmers match?

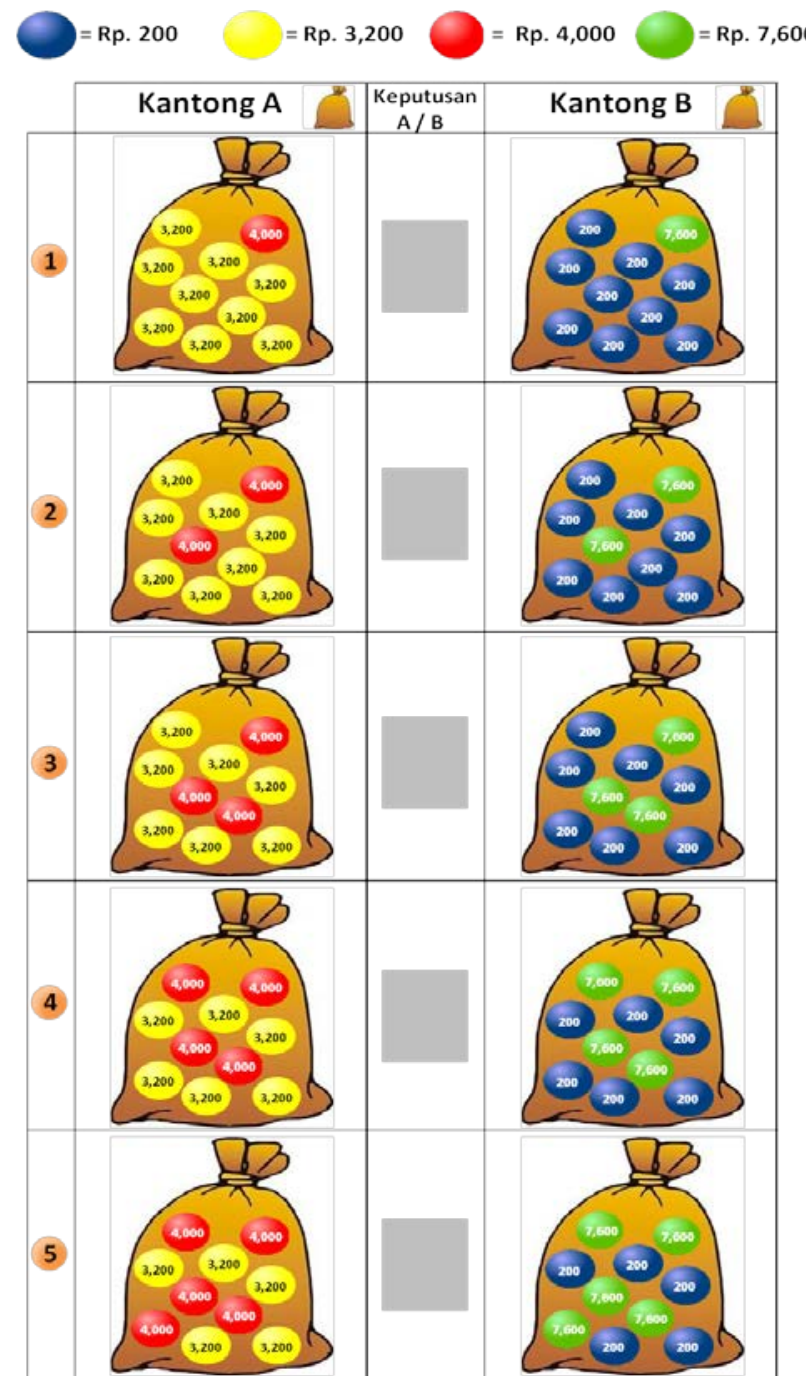

Figure A1. HL lottery

Source: Authors' illustration following Ihli and Musshoff (2013).

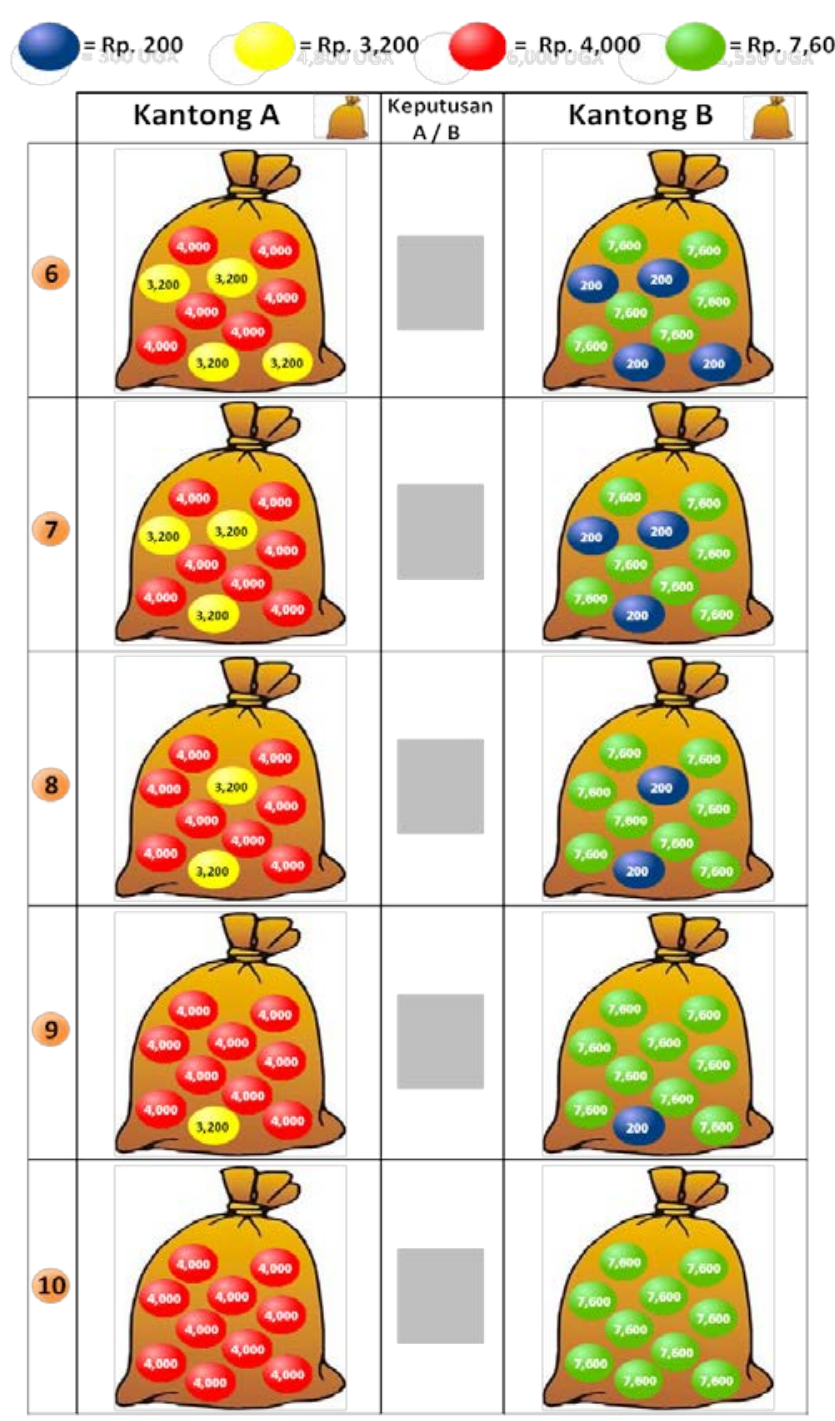

Figure A1 continued. HL lottery

Source: Authors' illustration following Ihli and Musshoff (2013). 


\section{Summary and Conclusions}

The articles of this dissertation investigate the experimental and field behaviour of smallscale farmers in the Jambi province on the Indonesian island of Sumatra. The first paper experimentally compares differently designed incentives for policy measures aimed at reducing fertiliser use in oil palm cultivation. This is done through the use of a business simulation game within a framed field experiment. The external validity of experimentally gained results, however, has been the topic of controversial discussions. Therefore, the second paper tests the external validity of experimentally gained results with almost the same farmers that participated in the business simulation game. This was accomplished by comparing the use of risk-influencing production inputs in rubber production with the experimentally measured risk attitude. In the following segment, we summarise each paper and conclude with a brief discussion and outlook for future use.

\section{Ex ante evaluation of policy measures}

The first article of this dissertation investigates the experimental ex ante evaluation of incentives to reduce the use of fertiliser in oil palm cultivation, which causes diverse negative externalities, e.g., ground water pollution, the emission of NOx or ground-level ozone (Keller and Matson, 1994; Sekhon, 1995; Veldkamp and Keller, 1997; Palm et al., 2002; Veldkamp et al., 2008; Hewitt et al., 2009). These negative externalities demand appropriate policy measures.

An ex ante test allows for testing policy measures at low costs. So far, most ex ante policy analyses apply the rational choice approach, which assumes a homo-oeconomicus-like behaviour. Since this assumption has recently been challenged by new insights from the field of experimental economics, it is necessary to take these new understandings into consideration (Veetil, 2011). We account for those insights by experimentally investigating policy measures, a method which is especially relevant for developing countries (Viceisza, 2012).

In this article, we test whether the design of an incentive for a policy measure influences its' effectiveness, sustainability and efficiency. We do this for the example of reducing the fertiliser usage with small-scale farmers who cultivate oil palm or have a realistic chance of doing so in the future. The research area is in Jambi province, on the Indonesian island of 
Sumatra. The three hypotheses of this article are "For the same effect on expected income, the H1: effectiveness, H2: sustainability, H3: efficiency of an incentive is independent of its design, i.e., reward or punishment, with different magnitudes and probabilities of occurrence".

The applied method is a business simulation game embedded in a framed field experiment. In this experiment, we simulated farmers operating an oil palm plantation for several cultivation periods. The compared incentives are differently designed, but constant in their effect on expected income. By testing for H1: effectiveness, we found that either certain punishment or uncertain reward are the most effective incentives. With respect to $\mathrm{H2}$ : sustainability, the uncertain reward turned out to be more sustainable than the certain punishment. Additionally, by testing for H3: efficiency, we found that a certain reward is the most efficient design. Thus, in order to achieve a strong and sustainable reduction in fertiliser, the use of an uncertain reward is the best design. Otherwise, if a policy aims to reduce fertiliser usage at low costs, a certain reward is the preferable design.

Both of these suggested incentives for fertiliser reduction, however, do not account for considerations or costs that might be relevant for practical application. For uncertain reward, i.e., the most effective and sustainable design, compliant behaviour is, per definition, not always rewarded. This could be seen as unfair and, thus, undermine the acceptance of such an incentive among farmers (Fehr and Schmidt, 1999). Additionally, it might be challenging to implement a process that is completely safe against corruption . A certain reward, i.e., the most efficient incentive design, necessitates the monitoring of each farmer. Individual monitoring could provoke high and, thus, decreases the efficiency in contrast to uncertain incentives.

It is unclear if these results are valid only in the aforementioned context, or if they are also valid in general. For example, it is possible that experimental results differ between, or even within, countries due to cultural differences (Herrmann et al., 2008; Balliet et al., 2011). Moreover, it could be that these results are specific for oil palm cultivation or for reducing the use of fertiliser. Furthermore, adopting the experimental layout could lead to different results, e.g., through the implementation of several possible production systems instead of one, or by adopting a more realistic generation of the output price or the production function. Consequently, further experiments are desirable to determine if the obtained results are robust in other contexts. 


\section{Comparing the use of risk-influencing production inputs and experimentally measured risk attitude}

The second article of this dissertation compares the use of risk-influencing production inputs with the experimentally measured risk attitude. In the research pertaining to agriculture, analysing risk and risk attitude is a primary focus (Chavas et al., 2010). However, it is long known that output risk can be influenced by risk-influencing production inputs (Just and Pope, 1978; 1979). It is vital for policy makers, as well as farmers to understand the influence of inputs on output risk, since it can help to manage such risks. However, in the case of rubber production, little is known about the influences of production inputs on output risk, further demanding investigation.

The external validity of experimentally obtained results towards field behaviour is controversially discussed in the literature. In this context, Levitt and List (2007) are sceptical about the external validity of such results, primarily due to the systematic differences between the lab and the field. On the contrary, Camerer (2011) argues that experimentally gained results have external validity, provided sufficient information is available. Thus, this controversial discussion surrounding the external validity of experimentally gained results demands further contribution.

In this article, a JP production function indicates inputs' influence on output risk, whereas an HL lottery measures farmers' risk attitude experimentally. Thus, we analyse the influence of inputs on output risk, as well as test the external validity of experimentally measured risk attitude. We do this for the case of small-scale rubber farmers in the Jambi province on the Indonesian island of Sumatra. The tested hypotheses are "H1: The amount of used production inputs has an influence on output risk" and "H2: More risk-averse farmers use more riskreducing and less risk-increasing inputs".

We found that fertiliser is a risk-decreasing input, whereas herbicides and plot size are riskincreasing production inputs. Therefore, we support the first hypothesis since these three production inputs have a significant influence on output risk. Moreover, we found that more risk averse farmers use more (risk-decreasing) fertiliser and less (risk-increasing) herbicides. Thus, we also support the second hypothesis. This indicates that for the use of fertiliser and herbicides, external validity was found for the experimentally measured risk attitude.

These results are relevant for several reasons. First, by comparing the use of risk-influencing production inputs and the experimentally measured risk attitude, we contribute to the 
ongoing discussion regarding the external validity of experimental results. This example is especially relevant, since influencing output risk with input use is a toll that is available for the vast majority of farmers. Second, we found evidence that in rubber production, output risk can be influenced by input use. This knowledge pertaining to methods for handling such output risks can be useful for developing appropriate policy measures, as well as being beneficial for farmers.

\section{Outlook}

For experiments like in the first article of this dissertation, the external validity is important, since it determines if results are valid for practical application (Levitt and List, 2007; Roe and Just, 2009; Camerer, 2011). Therefore, further investigation into the external validity of experimental results, e.g., by comparing experimental and field behaviour, would further show if results for the experiment are applicable to field behaviour. For example, it would be desirable to find a situation where a policy measure has been introduced, and then comparing the observed reaction towards a policy measure with the reaction from an ex ante experiment concerning the same measure. Fortunately, for the second phase of the CRC 990, such an experiment for testing the "Roundtable on Sustainable Palm Oil" (RSPO) or "Indonesian Sustainable Palm Oil" (ISPO)-certificates is already in the planning process.

The second article of this dissertation provides proof for the external validity of experimentally measured risk attitude. However, the differences in the experimental design to the first article of this dissertation does not allow to assume external validity per se, even though the research was conducted with nearly the same farmers that took part in the business simulation game. Therefore, it would be appealing to further verify the obtained results through additional investigation. Lence (2009) discusses the difficulties with estimating risk aversion in combination with the JP production function. In this regard, further research which compares the estimated with the experimentally measured risk attitude is already in the planning process within the CRC 990. This further research may bring valuable insight to the discussion concerning external validity. 


\section{References}

Balliet, D., Mulder, L.B. and Van Lange, P.A.M. (2011). 'Reward, punishment, and cooperation: A meta-analysis', Psychological Bulletin, Vol. 137: 594-615.

Camerer, C. (2011). 'The promise and success of lab-field generalizability in experimental economics: A critical reply to Levitt and List', Working Paper 1977749, (Los Angeles: Social Science Research Network).

Chavas, J.P., Chambers, R.G. and Pope, R.D. (2010). 'Production economics and farm management: a century of contributions', American Journal of Agricultural Economics, Vol. 92: 356-375.

Fehr, E., and Schmidt, K.M. (1999) 'A theory of fairness, competition, and cooperation', Quarterly Journal of Economics, Vol. 114: 817-868.

Herrmann, B., Thöni, C. and Gächter, S. (2008). 'Antisocial punishment across societies', Science, Vol. 319: 1362-1367.

Hewitt, C.N., MacKenzie, A.R., Di Carlo, P., Di Marco, C.F., Dorsey, J.R., Evans, M., Fowler, D., Gallagher, M.W., Hopkins, J.R., Jones, C.E., Langford, B., Lee, J.D., Lewis, A.C., Lim, S.F., McQuaid, J., Misztal, P., Moller, S.J., Monks, P.S., Nemitz, E., Oram, D.E., Owen, S.M., Phillips, G.J., Pugh, T.A.M., Pyle, J.A., Reeves, C.E., Ryder, J., Siong, J., Skiba, U. and Stewart, D.J. (2009). 'Nitrogen management is essential to prevent tropical oil palm plantations from causing ground-level ozone pollution', Proceedings of the National Academy of Sciences, Vol. 106: 18447-18451.

Just, R.E. and Pope, R.D. (1978). 'Stochastic specification of production functions and economic implications', Journal of Econometrics, Vol. 7: 67-86.

Just, R.E. and Pope, R.D. (1979). 'Production function estimation and related risk considerations', American Journal of Agricultural Economics, Vol. 61: 276-284.

Keller, M. and Matson, P.A. (1994). 'Biosphere-Atmosphere Exchange of Trace Gases in the Tropics: Evaluating the Effects of Land Use Changes', Global Atmospheric-Biospheric Chemistry, Vol. 48: 103-117.

Lence, S.H. (2009). 'Joint estimation of risk preferences and technology: flexible utility or futility?', American Journal of Agricultural Economics, Vol. 91: 581-598.

Levitt, S.D. and List, J.A. (2007). 'What do laboratory experiments measuring social preferences reveal about the real world?', The Journal of Economic Perspectives, Vol. 21: 153-174.

Palm, C.A., Alegre, J.C., Arevalo, L., Mutuo, P.K., Mosier, A.R. and Coe, R. (2002). 'Nitrous oxide and methane fluxes in six different land use systems in the Peruvian Amazon', Global Biogeochemical Cycles, Vol. 16: 1-21.

Roe, B.E. and Just, D.R. (2009). 'Internal and external validity in economics research: Tradeoffs between experiments, field experiments, natural experiments, and field data', American Journal of Agricultural Economics, Vol. 91: 1266-1271. 
Sekhon, G.S. (1995). 'Fertilizer-N use efficiency and nitrate pollution of groundwater in developing countries', Journal of Contaminant Hydrology, Vol. 20: 167-184.

Veetil, V. (2011). 'Conceptions of rationality in law and economics', European Journal of Law and Economics, Vol. 31: 199-228.

Veldkamp, E. and Keller, M. (1997). 'Nitrogen oxide emissions from a banana plantation in the humid tropics', Journal of Geophysical Research: Atmospheres, Vol. 102: 1588915898.

Veldkamp, E., Purbopuspito, J., Corre, M.D., Brumme, R. and Murdiyarso, D. (2008). 'Land use change effects on trace gas fluxes in the forest margins of Central Sulawesi, Indonesia', Journal of Geophysical Research: Biogeosciences,: Vol. 113: 1-11.

Viceisza, A. (2012). Treating the field as a lab: A basic guide to conducting economics (Washington, DC: International Food Policy Research Institute (IFPRI)). 